\title{
Modlitwa Pańska w świetle wzorów Janowych
}

\author{
Paweł M. Mucha \\ Poznań \\ pablomarco@wp.pl @ https://orcid.org/0000-0001-9926-6623
}

\section{Modlitwa Pańska jest tematem wielu prac naukowych. Przedmiotem badań bywa zarówno cała modlitwa ${ }^{1}$, jak i jej poszczególne prośby² ${ }^{2}$, a nawet trudne pojęcia ${ }^{3}$. Celem natomiast tej pracy jest pokazanie, że modlitwa ta, zarówno}

1 Np. H. Schürmann, Das Gebet des Herrn als Schlüssel zum Verstehen Jesu, wyd. 4, Verlag Herder, Freiburg-Basel-Wien 1981; E. Lohmeyer, Das Vater-unser, wyd. 5, Vandenhoeck \& Ruprecht, Göttingen 1962; J. Carmignac, Recherches sur le "Notre Père ", Letouzey \& Ané, Paris 1969; M. Bednarz, Ojcze nasz, Biblos, Tarnów 1999; J. Drozd, Ojcze nasz - modlitwa Pańska według współczesnej egzegezy, Księgarnia św. Jacka, Katowice 1983 (Attende Lectioni, 9).

2 Zob. np. J. A. Fitzmyer, And Lead Us Not into Temptation, „Biblica” 84 (2003) nr 2, s. 259-273, https://doi.org/10.2143/BIB.84.2.3194471; C. Blumenthal, ,... wie im Himmel so auf Erden“. Die räumlichen Implikationen der Vergebungsbitte des matthäischen Vaterunsers, „Zeitschrift für die neutestamentliche Wissenschaft” 108 (2017) nr 2, s. 191-211, https://doi.org/10.1515/znw-20170008; M. Gielen, „Und führe uns nicht in Versuchung". Die 6. Vater-Unser Bitte - eine Anfechtung für das biblische Gottesbild?, „Zeitschrift für die Neutestamentliche Wissenschaft und die Kunde der Älteren Kirche” 89 (2009) nr 3-4, s. 201-216, https://doi.org/10.1515/zntw.1998.89.3-4.201; R. Freudenberger, Zum Text Der Zweiten Vaterunserbitte, „New Testament Studies” 15 (1969) nr 4, s. 419-432, https://doi.org/10.1017/S0028688500019263; J. Neumann, Thy Will Be Done: Jesus's Passion in the Lord's Prayer, „Journal of Biblical Literature” 138 (2019) nr 1, s. 161-182, https://doi.org/10.15699/jbl.1381.2019.524397; K. Grayston, The Decline of Temptation - and the Lord's Prayer, „Scottish Journal of Theology” 46 (1993) nr 3, s. 279-296, https://doi.org/10.1017/ S0036930600044835; A. Salm, „Nie dopuść, abyśmy ulegli pokusie” - od Pisma Świętego do codziennej liturgii i modlitwy, „Ruch Biblijny i Liturgiczny” 63 (2010) nr 1, s. 73-77, https://doi.org/10.21906/ rbl.162; M. J. Brown, „Panem Nostrum”: The Problem of Petition and the Lord's Prayer, „The Journal of Religion” 80 (2000) nr 4, s. 595-614, https://doi.org/10.1086/490715; L. Drake, Did Jesus Oppose the prosbul in the Forgiveness Petition of the Lord's Prayer?, „Novum Testamentum” 56 (2014) nr 3, s. 233-244, https://doi.org/10.1163/15685365-12341447.

3 Zob. np. A. Harvey, Daily Bread, "The Journal of Theological Studies” 69 (2018) nr 1, s. 25-38, https://doi.org/10.1093/jts/flx242; T. Shearman, Our Daily Bread, „Journal of Biblical Literature” 53 (1934) nr 2, s. 110-117, https://doi.org/10.2307/3259878; J. Barr, 'Abbā isn't 'daddy', „The Journal of Theological Studies” 39 (1988) nr 1, s. 28-47, https://doi.org/10.1093/jts/39.1.28; C. Hemer,

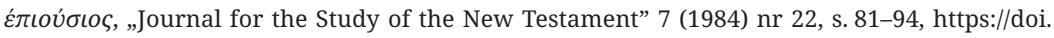
org/10.1177/0142064X8400702205; С. B. Houk, ПEIPALMOГ, The Lord's Prayer, and the Massah Tradition, „Scottish Journal of Theology” 19 (1966) nr 2, s. 216-225, https://doi.org/10.1017/ S0036930600002982; T. M. Dąbek, Boże synostwo a ludzkie braterstwo Teologia wezwania 
w Ewangelii Mateusza, jak i Łukasza, została skomponowana w oparciu o tzw. wzory Janowe. Kluczowe znaczenie ma tutaj ilość próśb u obu Ewangelistów. Mogą bowiem być one skutkiem kompozycji tej modlitwy według modeli Janowych, a to niesie ze sobą poważne konsekwencje.

\section{Struktura Modlitwy Pańskiej}

Modlitwa Pańska - oratio Dominica - jest szczególną modlitwą, której powstanie przypisuje się samemu Jezusowi ${ }^{4}$. Tertulian uważał Pater noster za streszczenie całej Ewangelii ${ }^{5}$. Dlatego modlitwa ta budziła i budzi duże zainteresowanie wśród uczonych, zarówno zagranicznych, jak i polskich ${ }^{6}$. W Ewangeliach są dwie wersje Modlitwy Pańskiej: u Mateusza (6, 9-13) i u Łukasza (11, 2b-4):

Mt 6, 9-13

Ojcze nasz, który jesteś w niebie, niech się święci imię Twoje!

Niech przyjdzie królestwo Twoje;

niech Twoja wola spełnia się na ziemi, tak jak

i w niebie.

Chleba naszego powszedniego daj nam dzisiaj;

i przebacz nam nasze winy, jak i my przebaczamy tym, którzy przeciw nam zawinili; i nie dopuść, abyśmy ulegli pokusie, ale nas zachowaj od złego!
Łk 11, 2b-4

Ojcze,

niech się święci Twoje imię;

niech przyjdzie Twoje królestwo!

Naszego chleba powszedniego dawaj nam na każdy dzień

i przebacz nam nasze grzechy, bo i my przebaczamy każdemu, kto nam zawini; i nie dopuść, byśmy ulegli pokusie.

Ojcze nasz, „Ruch Biblijny i Liturgiczny” 53 (2000) nr 3-4, s. 189-198, https://doi.org/10.21906/ rbl.506; J. Hennig, Our Daily Bread, „Theological Studies” 4 (1943) nr 3, s. 445-454, https://doi. org/10.1177/004056394300400306; A. Harvey, Difficult Texts: Matthew 6.11: Daily bread, „Theology” 119 (2016) nr 6, s. 403-406, https://doi.org/10.1177/0040571X16659237.

4 Katechizm Kościoła katolickiego, 2765.

5 De oratione, 1, PL 1, 1255.

6 Zob. np. bibliografię w: Elenchus of Biblica, Pontificio Istituto Biblico, Roma 1969-2011; J. Carmignac, Recherches sur le " Notre Père », Letouzey \& Ané, Paris 1969, s. 469-553. 
Jest jeszcze trzecia wersja Ojcze nasz, która znajduje się w Didache $(8,2)$. Ponieważ jednak jest ona bardzo zbliżona do Mateuszowego Pater noster, a Didache nie występuje w kanonie ksiąg Nowego Testamentu, ta wersja nie będzie tutaj omawiana ${ }^{7}$. Mateuszowa forma Ojcze nasz jest dłuższa od Łukaszowej i zawiera siedem próśb: trzy pierwsze są skierowane do Boga, cztery pozostałe natomiast do ludzkich potrzeb i spraw ${ }^{8}$. Struktura $\mathrm{x} / \mathrm{x}+1 \mathrm{ma}$ starotestamentalne korzenie ${ }^{9}$. Taka konstrukcja Ojcze nasz była więc nieprzypadkowa. Co więcej, liczba siedem ma w Biblii głębokie znaczenie pełni i doskonałości ${ }^{10}$. Wersja Łukaszowa składa się z pięciu próśb. Także ta liczba miała szczególne znaczenie ${ }^{11}$. Widać to wyraźnie po miejscach i ilości występowania liczb siedem i pięć w Biblii ${ }^{12}$. Krótsza wersja Łukaszowa mogła budzić pewne niezrozumienie i dlatego kopiści próbowali uzupełnić bądź dopasować krótszą wersję Łukaszową do dłuższej Mateuszowej ${ }^{13}$. Niektórzy w Mateuszowej

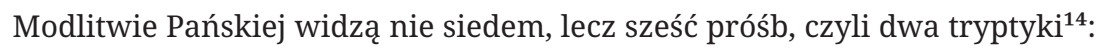

Trzy prośby dotyczące Boga i Jego czci

(1) Niech się święci imię Twoje;

(2) Niech przyjdzie królestwo Twoje;

(3) Niech Twoja wola spełnia się na ziemi, tak jak i w niebie.

7 Por. D. Clark, The Lord's Prayer. Origins and Early Interpretations, Brepols Publishers, Turnhout 2016, s. 83-174 (Studia Traditionis Theologiae, 21), https://doi.org/10.1484/M.STT-EB.5.110928; N. Ayo, The Lord's Prayer. A Survey Theological and Literary, University of Notre Dame Press, Notre Dame-London 1992; H. Klein, Das Vaterunser: Seine Geschichte und sein Verständnis bei Jesus und im frühen Christentum, [w:] Das Gebet im Neuen Testament: Vierte europäische orthodox-westliche Exegetenkonferenz in Sâmb̌ata de Sus, 4.-8. August 2007, hrsg. von H. Klein, V. Mihoc, K.-W. Niebuhr, C. Karakolis, Tübingen 2009, s. 77-114 (Wissenschaftliche Untersuchungen zum Neuen Testament, 249), https://doi.org/10.1628/978-3-16-151538-5.

8 Słowa nadziei. Prośby Modlitwy Pańskiej, oprac. i red. M. Mróz, Wydawnictwo Uniwersytetu Mikołaja Kopernika, Toruń 2005 (Euntes Docete, 4).

9 Zob. W. M. W. Roth, The Numerical Sequence $x / x+1$ in the Old Testament, „Vetus Testamentum” 12 (1962) nr 1, s. 300-311, https://doi.org/10.1163/156853362X00182.

10 J. Flis, Struktura i treść krótszej wersji modlitwy Ojcze nasz ( $₫ k$ 11, 2b-4), „Colloquia Theologica Ottoniana” 2 (2013), s. 25.

11 Tamże, s. 29-30.

12 J. Flis, Konkordancja Starego i Nowego Testamentu do Biblii Tysiąclecia, wyd. 4, Vocatio, Warszawa 2004.

13 Novum Testamentum Graece, begründet von E. und E. Nestle, hrsg. von B. und K. Aland, J. Karavidopoulos, C. M. Martini, B. M. Metzger, wyd. 28, Deutsche Bibelgesellschaft, Stuttgart 2012.

14 Np. R. T. France, The Gospel of Matthew, William B. Eerdmans Publishing Company, Grand RapidsCambridge 2007, s. 242-243 (The New International Commentary on the New Testament). 
Trzy prośby dotyczące ludzkich potrzeb i spraw

(1) Chleba naszego powszedniego daj nam dzisiaj;

(2) I przebacz nam nasze winy, jak i my przebaczamy tym, którzy przeciw nam zawinili;

(3) I nie dopuść, abyśmy ulegli pokusie, ale nas zachowaj od złego!

Także w Łukaszowej wersji niektórzy doszukują się aż sześciu próśb ${ }^{15}$. W pierwszej Ewangelii kanonicznej widać szczególne zamiłowanie jej autora do poezji, historii i dialektyki ${ }^{16}$, podział więc na dwa tryptyki podkreślałby po prostu, że Ojcze nasz należy do tradycji starożytnej żydowskiej poezji religijnej ${ }^{17}$. Pod pewnymi względami przypomina Kadisz i modlitwę osiemnastu błogosławieństw ${ }^{18}$. W pierwotnym Kościele Pater noster mógł być odmawiany tak, jak w ówczesnych synagogach modlitwa osiemnastu błogosławieństw ${ }^{19}$.

U podstaw Mateuszowej i Łukaszowej wersji miałaby leżeć jedna aramejska przedkanoniczna wersja Modlitwy Pańskiej, będąca dwuzwrotkowym wierszem $^{20}$. Lohmeyer dostrzegł w tłumaczeniu tej modlitwy na aramejski siedem wersetów, z których każdy miałby się składać z siedmiu sylab ${ }^{21}$. Dopiero z czasem miałaby być przetłumaczona wiernie na grecki ${ }^{22}$. Nie moż-

15 G. Schwarz, Matthäus VI. 9-13/Lukas XI. 2-4: Emendation und Rückübersetzung, „New Testament Studies” 15 (2009) nr 2, s. 246, https://doi.org/10.1017/S0028688500019068.

16 M. C. Bradley, Matthew. Poet, Historian, Dialectician, Peter Lang, New York-Bern-Berlin-BruxellesFrankfurt am Main-Oxford-Wien 2007, https://doi.org/10.3726/978-1-4539-0694-1.

17 M. W. Martin, The Poetry of the Lord's Prayer: A Study in Poetic Device, „Journal of Biblical Literature” 134 (2015) nr 2, s. 347-372, https://doi.org/10.15699/jbl.1342.2015.2804.

18 Zob. M. Rosik, Judaistyczne tło Modlitwy Pańskiej (Mt 6, 9-13), „Zeszyty Naukowe Centrum Badań im. Edyty Stein” 4 (2008), s. 41-49; N. Mendecki, Modlitwa „osiemnastu błogosławieństw”, „Ruch Biblijny i Liturgiczny” 37 (1984) nr 2, s. 140-143, https://doi.org/10.21906/rbl.1270. Zob. także D. Instone-Brewer, The Eighteen Benedictions and the Minim before 70 CE, „The Journal of Theological Studies” 54 (2003) nr 1, s. 25-44, https://doi.org/10.1093/jts/54.1.25; L. Finkelstein, The Development of the Amidah, „The Jewish Quarterly Review” 16 (1925) nr 1, s. 1-43, https:// doi.org/10.2307/1451747; L. Liebreich, The Intermediate Benedictions of the Amidah, „The Jewish Quarterly Review” 42 (1952) nr 4, s. 423-426, https://doi.org/10.2307/1453019; A. Mishcon, The Origin of את צמח דוד and Its Place in the 'Amidah, „The Jewish Quarterly Review” 18 (1927) nr 1, s. 37-43, https://doi.org/10.2307/1451757; A. Marmorstein, The Amidah of the Public Fast Days, „The Jewish Quarterly Review" 15 (1925) nr 3, s. 409-418, https://doi.org/10.2307/1451587; R. Kimelman, The Daily 'Amidah and the Rhetoric of Redemption, „The Je-wish Quarterly Review” 79 (1988) nr 2-3, s. 165-197, https://doi.org/10.2307/1454251.

19 G. Bahr, The Use of the Lord's Prayer in the Primitive Church, „Journal of Biblical Literature” 84 (1965) nr 2, s. 153-159, https://doi.org/10.2307/3264137.

20 G. Schwarz, Matthäus VI. 9-13/Lukas XI. 2-4: Emendation und Rückübersetzung, art. cyt.

21 E. Lohmeyer, Das Vater-unser, wyd. 5, Vandenhoeck \& Ruprecht, Göttingen 1962, s. 16.

22 F. Mickiewicz, Ewangelia według św. Łukasza, cz. 1: Rozdziały 1-11, Edycja Świętego Pawła, Częstochowa 2011, s. 579 (Nowy Komentarz Biblijny. Nowy Testament, 3.1). 
na jednak wykluczyć, że oryginał był nie po aramejsku, lecz po hebrajsku²3, gdyż na samym początku chrześcijaństwa hebrajski był językiem mówionym i pisanym ${ }^{24}$. Chociaż judaistyczne tło jest wyraźnie widoczne ${ }^{25}$, to jednak jest to nowa modlitwa uczniów Nowego Przymierza ${ }^{26}$. Niektórzy uważają Pater noster za modlitwę eschatologiczną ${ }^{27}$, inni nie podzielają tego zdania ${ }^{28}$. Pewny natomiast jest społeczny, tzn. wspólnotowy charakter tej modlitwy ${ }^{29}$.

Mateuszowa Modlitwa Pańska zawiera jednak siedem próśb ${ }^{30}$, co jest uwydatniane nawet w samych tytułach $\operatorname{prac}^{31}$, a Łukaszowa pięć, chociaż takie zakończenie Ojcze nasz może budzić wątpliwości ${ }^{32}$. U Mateusza umieszczona jest w centralnej części Kazania na Górze, co podkreśla jej szczególne

23 J. Carmignac, Hebrew Translations of the Lord's Prayer: A Historical Survey, [w:] Biblical and Near Eastern Studies. Essays in Honor of William Sanford LaSor, ed. by G. A. Tuttle, Eerdmans, Grand Rapids 1978, s. 19-79; A. Ponomariov, The Lord's Prayer in a Wider Setting: a New Hebrew Reconstruction, „Journal of Northwest Semitic Languages” 41 (2015) nr 1, s. 71-100.

$24 \mathrm{~J}$. Grintz, Hebrew as the Spoken and Written Language in the Last Days of the Second Temple, ,Journal of Biblical Literature” 79 (1960) nr 1, s. 32-47, https://doi.org/10.2307/3264497; P. Muchowski, Język hebrajski qumrański, jego zasięg i status społeczny, „Ruch Biblijny i Liturgiczny” 51 (1998) nr 3, s. 161-168, https://doi.org/10.21906/rbl.670.

25 M. Rosik, Judaistyczne tło Modlitwy Pańskiej (Mt 6, 9-13) w świetle idei ojcostwa Bożego w Kazaniu na górze, „Verbum Vitae” 20 (2011), s. 115-138.

26 A. Paciorek, Nowa modlitwa uczniów Nowego Przymierza (Mt 6, 9-13), „Verbum Vitae” 4 (2003), s. $157-175$.

27 Np. R. E. Brown, The Pater Noster as an Eschatological Prayer, „Theological Studies” 22 (1961) nr 2, s. 175-208, https://doi.org/10.1177/004056396102200201; J. Jeremias, The Lord's Prayer in Modern Research, „The Expository Times” 71 (1960) nr 5, s. 141-146, https://doi. org/10.1177/001452466007100504; E. Lohmeyer, Das Vater-unser, wyd. 5, Bandenhoed \& Rupercht, Göttingen 1962; P. Trudinger, The 'Our Father' in Matthew as Apocalyptic Eschatology, „The Downside Review” 107 (1989) nr 366, s. 49-54, https://doi.org/10.1177/001258068910736604.

28 Np. J. B. Gibson, Matthew 6:9-13//Luke 11:2-4: An Eschatological Prayer?, „Biblical Theology Bulletin” 31 (2001) nr 3, s. 96-105, https://doi.org/10.1177/014610790103100304; S. Van Tilborg, A Form-Criticism of the Lord's Prayer, „Novum Testamentum” 14 (1972) nr 2, s. 94-105, https:// doi.org/10.2307/1560176.

29 F. Gryglewicz, Społeczny charakter Modlitwy Pańskiej, ,Ruch Biblijny i Liturgiczny” 3 (1950) nr 3, s. 207-219, https://doi.org/10.21906/rbl.2415.

30 Katechizm Kościoła katolickiego, 2803-2854.

31 Np. M. Jaworska, Pater noster: siedem próśb do Ojca, „Ateneum Kapłańskie” 140 (2003) z. 1, s. 21-36; D. Wenham, The Sevenfold Form of the Lord's Prayer in Matthew's Gospel, „The Expository Times” 121 (2010) nr 8, s. 377-382, https://doi.org/10.1177/0014524610364409.

32 Por. W. Popkes, Die letzte Bitte des Vater-Unser Formgeschichtliche Beobachtungen zum Gebet Jesu, „Zeitschrift für die Neutestamentliche Wissenschaft und die Kunde der Älteren Kirche” 81 (1990) nr 1-2, s. 1-20, https://doi.org/10.1515/zntw.1990.81.1-2.1. 
przesłanie odnośnie do modlitwy i moralności ${ }^{33}$. Nie może zatem dziwić fakt, że to właśnie wersja Mateuszowa budzi większe zainteresowanie niż krótsza Łukasza ${ }^{34}$.

Pomimo wyraźnych podobieństw można łatwo dostrzec różnice pomiędzy dwoma wersjami Modlitwy Pańskiej. Proponowano różne rozwiązania wyjaśnienia istotnych różnic pomiędzy tymi dwoma wersjami Ojcze nasz. Najprościej można je wytłumaczyć na cztery sposoby ${ }^{35}$ :

- Jezus nauczył tej modlitwy w dwóch różnych wersjach ${ }^{36}$,

- Mateusz przekazał pierwotną wersję Ojcze nasz, którą skrócił Łukasz ${ }^{37}$,

- krótsza wersja Łukaszowa jest starsza, rozszerzona później przez Mateusza ${ }^{38}$,

- obie wersje reprezentują różne tradycje przekazane niezależnie od siebie ${ }^{39}$.

Nowe światło na kompozycję tej modlitwy rzucają tzw. wzory Janowe. Okazuje się bowiem, że struktura Modlitwy Pańskiej może być skutkiem zastosowania modeli Janowych, które podkreślają godność Maryi jako Matki Pana.

33 O. O'Donovan, Prayer and Morality in the Sermon on the Mount, „Studies in Christian Ethics” 22 (2009) nr 1, s. 21-33, https://doi.org/10.1177/0953946808100224; D. E. Garland, The Lord's Prayer in the Gospel of Matthew, „Review \& Expositor” 89 (1992) nr 2, s. 215-228, https://doi. org/10.1177/003463739208900205.

34 Zob. bibliografię odnośnie obu wersji np. w: P. Ostański, Bibliografia biblistyki polskiej 19451999, t. 1-2, Uniwersytet im. Adama Mickiewicza Wydział Teologiczny Redakcja Wydawnictw, Poznań 2002 (Series Bibliographica, 1); P. Ostański, Bibliografia biblistyki polskiej 2000-2009, t. 3-4, Uniwersytet im. Adama Mickiewicza Wydział Teologiczny Redakcja Wydawnictw, Poznań 2010 (Series Bibliographica, 2); P. Ostański, Bibliografia biblistyki polskiej 2010-2013/2014, t. 5, Uniwersytet im. Adama Mickiewicza Wydział Teologiczny, Poznań 2015 (Series Bibliographica, 3).

35 L. Mateja, Dwie wersje Modlitwy Pańskiej odczytane w kluczu inicjacyjnym, „Vox Patrum” 67 (2017), s. 389, https://doi.org/10.31743/vp.3406; F. Mickiewicz, Ewangelia według św. Łukasza, dz. cyt., cz. 1, s. 577-578; por. M. D. Goulder, The Composition of the Lord's Prayer, „The Journal of Theological Studies” 14 (1963) nr 1, s. 32, https://doi.org/10.1093/jts/XIV.1.32; R. Hammerling, The Wondrous Origins of the Lord's Prayer, [w:] The Lord's Prayer in the Early Church. The Pearl of Great Price, Palgrave Macmillan, New York 2010, s. 11-44, https://doi.org/10.1057/9780230113084_3.

36 Np. Orygenes, De oratione, 18, 3; L. Mateja, Dwie wersje Modlitwy Pańskiej odczytane w kluczu inicjacyjnym, „Vox Patrum” 67 (2017), s. 389-401, https://doi.org/10.31743/vp.3406.

37 Św. Augustyn, De Fide. Spe Et Charitate, 115-116, PL 40, 285-286.

38 Np. G. N. Stanton, The Gospels and Jesus, wyd. 2, Oxford University Press, Oxford-New York 2002, s. 6-11.

39 G. Schwarz, Matthäus VI. 9-13/Lukas XI. 2-4: Emendation und Rückübersetzung, art. cyt., s. 233. 


\section{Wzory Janowe}

W Ewangelii Jana pojawia się jedna z najbardziej tajemniczych liczb w całej Biblii. W J 21, 11 mowa jest o 153 wielkich rybach złowionych przez uczniów Jezusa na Jego osobiste polecenie po nieudanym wcześniej połowie. Rozdział 21, w którym występuje liczba 153 ryb, znajduje się po pierwszym zakończeniu czwartej Ewangelii kanonicznej ${ }^{40}$, rzucając nowe światło na życie Jezusa poprzez Jego chrystofanię ${ }^{41}$. Liczba tych ryb stanowiła od dawna dużą zagadkę dla uczonych biblijnych, a wcześniej także dla Ojców Kościoła. Wielu uważa, że jest to rzeczywista liczba ryb złowionych przez tych kilku uczniów ${ }^{42}$. Byli z zawodu rybakami, a ryby w I wieku były ważnym źródłem dochodu w Galilei ${ }^{43}$, więc ich policzenie wydaje się czymś naturalnym. Jednak trudno Ewangelię Jana traktować literalnie ${ }^{44}$. Proponowano więc różne wyjaśnienia znaczenia tej liczby ${ }^{45}$. Niektóre z nich są nie tylko ciekawe, ale także godne uwagi ${ }^{46}$ :

40 Zob. H. Roose, Joh 20,30f.: Ein (un)passender Schluss? Joh 9 und 11 als primäre Verweisstellen der Schlussnotiz des Johannesevangeliums, ,Biblica” 84 (2003) nr 3, s. 326-343, https://doi.org/10.2143/ BIB.84.3.3194477; M. Martin, A Note on the Two Endings of John, „Biblica” 87 (2006) nr 4, s. 523-525, https://doi.org/10.2143/BIB.87.4.3189067; por. P. Minear, The Original Functions of John 21, „Journal of Biblical Literature” 102 (1983) nr 1, s. 85-98, https://doi.org/10.2307/3260747.

41 Por. G. O'Collins, 'His Life Rose With Him'-John 21 and the Resurrection of Jesus, „Irish Theological Quarterly” 84 (2019) nr 2, s. 195-211, https://doi.org/10.1177/0021140019829327; P. E. Spencer, Narrative Echoes in John 21: Intertextual Interpretation and Intratextual Connection, ,Journal for the Study of the New Testament” 22 (2000) nr 75, s. 49-68, https://doi.org/10.1177/0142064X0002207504.

42 Np. J. H. Bernard, A Critical and Exegetical Commentary on the Gospel according to St. John, T. \& T. Clark, Edinburgh 1928, t. 2, s. 699-700.

43 R. Hakola, The Production and Trade of Fish as Source of Economic Growth in the First Century ce Galilee: Galilean Economy Reexamined, „Novum Testamentum” 59 (2017) nr 2, s. 111-130, https:// doi.org/10.1163/15685365-12341561; por. K.-H. Ostmeyer, Armenhaus und Räuberhöhle? Galiläa zur Zeit Jesu, „Zeitschrift für die Neutestamentliche Wissenschaft und die Kunde der Älteren Kirche” 96 (2005) nr 3-4, s. 147-170, https://doi.org/10.1515/zntw.2005.96.3-4.147; zob. M. Rapinchuk, The Galilee and Jesus in Recent Research, „Currents in Biblical Research” 2 (2004) nr 2, s. 197-222, https://doi.org/10.1177/1476993X0300200204.

44 O. T. Owen, One Hundred and Fifty Three Fishes, „The Expository Times” 100 (1988) nr 2, s. 52, https://doi.org/10.1177/001452468810000204; zob. także M. J. J. Menken, Numerical Literary Techniques in John. The Fourth Evangelist's Use of Numbers of Words and Syllables, Brill, Leiden 2014 (Novum Testamentum. Supplements, 55), https://doi.org/10.1163/9789004266667.

45 R. A. Culpepper, Designs for the Church in the Imagery of John 21:1-14, [w:] Imagery in the Gospel of John. Terms, Forms, Themes, and Theology of Johannine Figurative Language, eds. J. Frey, J. G. Van der Watt, R. Zimmermann, G. Kern, Mohr Siebeck, Tubingen 2006, s. 383-394 (Wissenschaftliche Untersuchungen zum Neuen Testament, 200).

46 R. Wróbel, Chrystofania nad Jeziorem Tyberiadzkim (J 21, 1-14). Problemy interpretacyjne i znaczenie, „Ruch Biblijny i Liturgiczny” 60 (2007) nr 3, s. 194, przypis 44, https://doi.org/10.21906/ 
- Św. Augustyn zauważył, że suma liczb naturalnych od 1 do 17 wynosi 153, a liczba 17 jest sumą 10 (przykazań) oraz 7 (darów Ducha Świętego) ${ }^{47}$,

- $\quad$ św. Hieronim twierdził, że w tamtym czasie Grecy znali 153 gatunki $\mathrm{ryb}^{48}$,

- $\quad$ św. Cyryl z Aleksandrii uważał, że liczba 153 ma znaczenie symboliczne, gdyż jest złożona z liczby 100 reprezentującej pogan, liczby 50 przypisanej Izraelowi oraz z liczby 3 oznaczającej Trójcę Świętą ${ }^{49}$,

- Heinz Kruse twierdził, że liczba 153 jest wartością numeryczną he-

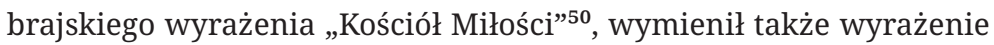
„Dzieci Boga” jako spełniające jego obliczenia"

- $\quad$ Robert Eisler sądził, że jest to suma wartości numerycznych dwóch greckich słów $\sigma \iota \omega \omega \nu$ („Szymon”) i ı $\chi \theta \cup \sigma$ („ryba”) ${ }^{52}$,

- John A. Emerton zwrócił uwagę, że wartość numeryczna dwóch hebrajskich słów En-Gedi i En-Eglaim w Ez 47, 9-10 wynosi 17 i 15353,

rbl.371.

47 PL 35, 1963-1964; zob. także M. Wojciechowski, Certains aspects algébriques de quelques nombres symboliques de la Bible (Gen 5; Gen 14, 14; Jn 21, 11), „Biblische Notizen” 23 (1984), s. 29-31.

48 PL 25, 474C; zob. także R. M. Grant, “One Hundred Fifty-Three Large Fish” (John 21:11), „Harvard Theological Review” 42 (1949) nr 4, s. 273-275, https://doi.org/10.1017/S0017816000024329; J. M. Ross, One Hundred and Fifty-Three Fishes, „The Expository Times” 100 (1989) nr 10, s. 375, https://doi.org/10.1177/001452468910001005; A. Pitta, Ichthys ed opsarion in Gv 21,1-14: Semplice variazione lessicale o differenza con valore simbolico?, „Biblica” 71 (1990) nr 3, s. 348-364, https:// doi.org/10.2143/BIB.71.3.3217765.

49 PG 74, 745.

50 H. Kruse, Magni Pisces Centum Quinquaginta Tres, „Verbum Domini” 38 (1960), s. 129-149.

51 Por. J. Romeo, Gematria and John 21:11: The Children of God, „Journal of Biblical Literature” 97 (1978) nr 2, s. 263-264, https://doi.org/10.2307/3265625.

52 R. Eisler, Orpheus, The Fisher. Comparative Studies in Orphic and Early Christian Cult Symbolism, J. M. Watkins, London 1921, s. 119.

53 J. A. Emerton, The Hundred And Fifty-Three Fishes in John XXI. 11, „The Journal of Theological Studies” 9 (1958) nr 1, s. 86-89, https://doi.org/10.1093/jts/IX.1.86; zob. także: P. R. Ackroyd, The 153 Fishes in John XXI. 11 - A Further Note, „The Journal of Theological Studies” 10 (1959) nr 1, s. 94, https://doi.org/10.1093/jts/X.1.94; J. A. Emerton, Some New Testament Notes, „The Journal of Theological Studies” 11 (1960) nr 2, s. 335-336, https://doi.org/10.1093/jts/XI.2.329; B. Grigsby, Gematria and John 21 - Another Look at Ezekiel 4710, „The Expository Times” 95 (1984) nr 6, s. 177-178, https://doi.org/10.1177/001452468409500607; B. Grigsby, 'If Any Man Thirsts...': Observations on the Rabbinic Background of John 7,37-39, „Biblica” 67 (1986) nr 1, s. 101-108, https://doi.org/10.2143/BIB.67.1.3217958; M. Rastoin, Encore une fois les 153 poissons (Jn 21,11), „Biblica” 90 (2009) nr 1, s. 84-92, https://doi.org/10.2143/BIB.90.1.3188895. 
- Neil J. McEleney uważa, że liczba 153 jest wartością numeryczną trzech greckich liter $\iota \chi(70+3+80)$, które są akrostychem greckiego wyrażenia

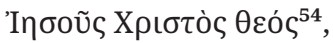

- Douglas E. Oakman dopatruje się politycznego znaczenia tej liczby55. Powyższe interpretacje zasługują na uwagę, ale nie są przekonywujące ${ }^{56}$, dlatego wciąż proponowane są nowe rozwiązania ${ }^{57}$. Trudno także uważać liczbę 153 w J 21, 11 za istotny czynnik decydujący o jedności całej Ewangelii Jana $^{58}$. Jest wprawdzie liczbą trójkątną, która jest szczególnym przypadkiem tzw. liczb wielokątnych, ale to nie jedyny taki przypadek w Nowym Testamencie ${ }^{59}$. Wyszukiwanie rozwiązań opartych na przypadkowych skojarzeniach wydaje się bezsensowne ${ }^{60}$. Warto zauważyć, że żadna z tych interpretacji nie uwzględnia występowania tej liczby poza Biblią ${ }^{61}$. Liczbę 153 można znaleźć np. w objawieniach fatimskich ${ }^{62}$. Fakt ten może wskazywać, że ta tajemnicza liczba jest w jakiś sposób związana z Matką Bożą. Pojawia się przecież w Ewangelii Jana, któremu Jezus powierzył swoją Matkę umierając na krzyżu (por. J 19, 25-27) i tytułując Ją dostojnie „Niewiasta”63.

54 Por. N. J. McEleney, 153 Great Fishes (John 21:11) - Gematriacal Atbash, „Biblica” 58 (1977) nr 3, s. 411-417, http://www.jstor.org/stable/42610891.

55 Por. D. E. Oakman, The Political Meaning of a Cipher - John 21:11: In memory of an unforgettable friend and scholar John J. Pilch, „Biblical Theology Bulletin” 47 (2017) nr 2, s. 87-94, https://doi. org/10.1177/0146107917697904.

56 C. Marucci, Il significato del numero 153 in Gv 21,11, „Rivista Biblica” 52 (2004) nr 4, s. 403-440.

57 Zob. T. Nicklas, '153 große Fische' (Joh 21, 11) Erzählerische Ökonomie und 'johanneischer Überstieg', „Biblica” 84 (2003) nr 3, s. 366-387, https://doi.org/10.2143/BIB.84.3.3194479; M. Oberweis, Die Bedeutung der neutestamentlichen »Rätselzahlen “ 666 (Apk 13 18) und 153 (Joh 21 11), „Zeitschrift für die Neutestamentliche Wissenschaft und die Kunde der Älteren Kirche” 77 (2009) nr 3-4, s. 226-241, https://doi.org/10.1515/zntw.1986.77.3-4.226; S. T. Tovar, Sobre los 153 peces en Jn 21, 11. ¿Encierra el 153 un notarikón? ¿Remite a los no judíos?, „Liber Annuus” 62 (2012), s. 107-117, https://doi.org/10.1484/J.LA.5.101302.

58 Por. R. Bauckham, The 153 Fish and the Unity of the Fourth Gospel, „Neotestamentica” 36 (2002) nr 1-2, s. 77-88, http://www.jstor.org/stable/43049111.

59 F. H. Colson, Triangular Numbers in the New Testament, „The Journal of Theological Studies” 16 (1915) nr 10, s. 67-76, https://doi.org/10.1093/jts/os-XVI.10.67; S. Hart, Triangular Numbers, „The Journal of Theological Studies” 17 (1916) nr 10, s. 76-77, https://doi.org/10.1093/jts/os-XVII.10.76.

60 Zob. M. Kiley, Three More Fish Stories (John 21:11), „Journal of Biblical Literature” 127 (2008) nr 3, s. 529-531, https://doi.org/10.2307/25610138.

61 Por. G. Brooke, 4Q252 and the 153 Fish of John 21:11, [w:] Antikes Judentum und Frühes Christentum, De Gruyter, Berlin-Boston 1999, s. 253-265, https://doi.org/10.1515/9783110806069.

62 P. M. Mucha, Mother of the Lord and the 153 large fishes in John 21 : 11, „Ruch Biblijny i Liturgiczny” 62 (2009) nr 4, s. 298-299, https://doi.org/10.21906/rbl.222.

63 A. Nalewaj, „Matka Jezusa” $i$ „Niewiasta” jako tytuły Maryi w czwartej Ewangelii, „Ruch Biblijny i Liturgiczny” 63 (2010) nr 1, s. 13-30, https://doi.org/10.21906/rbl.158. 
Okazuje się, że sam autor czwartej Ewangelii podpowiedział, co oznacza liczba 153 w J 21, 11. Liczba ta pojawia się w perykopie zawierającej chrystofanię nad Jeziorem Tyberiadzkim (J 21, 1-14) ${ }^{64}$, której istotną osnową jest obfity połów. Perykopa o obfitym połowie jest także w Ewangelii Łukasza (Łk 5,1-11), ale pomiędzy tymi dwoma opowiadaniami są istotne różnice. Kluczową różnicą u Jana jest liczba uczniów, która jest wskazówką do odczytania ukrytego znaczenia liczby $153 \mathrm{w} \mathrm{J} 21,11^{65}$ :

- w J 21, 2 wymienionych jest pięciu uczniów z imienia (Szymon Piotr, Tomasz zwany Didymos, Natanael z Kany Galilejskiej, synowie Zebedeusza) oraz dwóch, których tożsamości nie da się ustalić; tych pięciu nazwanych uczniów i dwóch bez tożsamości złowiło 153 ryby (J 21, 11),

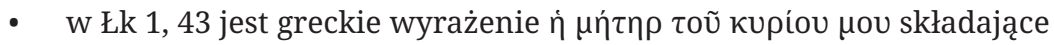

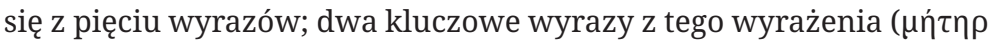
kupíou) mają wartość numeryczną 153.

Liczby pięć i dwa są tutaj kluczowe. Jest to tzw. drugi wzór Janowy 5+2. Podkreśla on godność Maryi jako Matki Pana (Łk 1, 43) ${ }^{66}$. Tych dwóch uczniów bez imienia stanowi jasną podpowiedź do odczytania znaczenia liczby $153 \mathrm{w} \mathrm{J} \mathrm{21,} 11$.

Prawdopodobnie jednak w tekście pierwotnym wymienionych było jedynie pięciu uczniów z imienia, a dwóch bez imienia stanowiło marginalną glosę, która z czasem została włączona do tekstu właściwego ${ }^{67}$. Redaktor Ewangelii Jana wymienił zatem tylko pięciu uczniów. Mogłoby się wydawać, że w ten sposób nie dał żadnej podpowiedzi, jak należy odczytać liczbę 153 w J 21, 11. Podając jednak pięciu uczniów z imienia, zawarł wyraźną wskazówkę do podkreślania godności Maryi jako Matki Pana:

- J 21, 2 wymienia trzech uczniów bezpośrednio z imienia (Szymon Piotr, Tomasz zwany Didymos, Natanael z Kany Galilejskiej) oraz dwóch uczniów, nie podając ich imion bezpośrednio, ale ustalenie ich tożsamości nie jest trudne (synowie Zebedeusza, czyli Jakub i Jan); tych trzech

64 Zob. R. Wróbel, Chrystofania nad Jeziorem Tyberiadzkim (J 21, 1-14). Problemy interpretacyjne i znaczenie, „Ruch Biblijny i Liturgiczny” 60 (2007) nr 3, s. 185-208, https://doi.org/10.21906/rbl.371.

65 P. M. Mucha, Mother of the Lord and the 153 large fishes in John 21:11, „Ruch Biblijny i Liturgiczny” 62 (2009) nr 4, s. 300, https://doi.org/10.21906/rbl.222; P. M. Mucha, What was the Origin of Number 153?, „Ruch Biblijny i Liturgiczny” 66 (2013) nr 2, s. 101, https://doi.org/10.21906/rbl.62.

66 Por. M. Bockmuehl, The Son of David and his Mother, „The Journal of Theological Studies” 62 (2011) nr 2, s. 476-493, https://doi.org/10.1093/jts/flr101.

67 M.-J. Lagrange, Évangile selon Saint Jean, wyd. 7, Gabalda, Paris 1948, s. 523 (Études Bibliques, 13). 
uczniów wymienionych bezpośrednio z imienia oraz dwóch synów Zebedeusza złowiło 153 ryby $(\mathrm{J} 21,11)$,

- $\quad$ po opuszczeniu trzech mało istotnych słów z greckiego wyrażenia

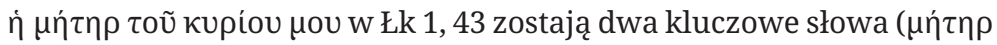
kupíou), których wartość numeryczna wynosi 153.

Liczby trzy i dwa są tutaj kluczowe. Jest to tzw. pierwszy wzór Janowy 3+2. Także on podkreśla godność Maryi jako Matki Pana. U Jana są zatem dwa klucze podkreślające godność Maryi jako Matki Pana: pierwszy wzór $3+2$ oraz drugi wzór $5+2$.

Warto zauważyć, że Janowy obfity połów (J 21, 1-14) ma paralelę u Łukasza

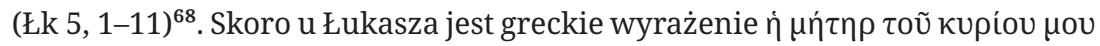
(Łk 1, 43), a klucze do jego odczytania znajdują się w Ewangelii Jana (J 21, 2), to Jan musiał znać Ewangelię Łukasza i przeredagował Łukaszowy obfity połów (por. J 11, 1) ${ }^{69}$. Pozwala to odtworzyć proces zmiany liczby uczniów biorących udział w połowie:

(1) Łukasz wymienia trzech uczniów: Piotra, Jakuba i Jana (Łk 5, 1-11) ${ }^{70}$,

(2) autor czwartej Ewangelii kanonicznej zmodyfikował Łukaszowy połów ryb i zgodnie z pierwszym wzorem Janowym 3+2 dodał do trzech uczniów wymienionych przez Łukasza dwóch innych, mianowicie Tomasza Didymosa i Natanaela ${ }^{71}$,

68 Por. R. Pesch, Der reiche Fischfang: Lk 5,1-11/Jo 21,1-14. Wundergeschichte, Berufungserzählung, Erscheinungsbericht, Patmos-Verlag, Düsseldorf 1969; R. E. Brown, The Gospel according to John (XIII-XXI), Doubleday, Garden City 1970, s. 1090 (Analecta Biblica, 29a).

69 Por. G. Blaskovic, Die Erzählung vom reichen Fischfang (Lk 5,1-11; Joh 21,1-14). Wie Johannes eine Erzählung aus dem Lukasevangelium für seine Zwecke umschreibt, [w:] Johannes aenigmaticus. Studien zum Johannesevangelium für Herbert Leroy, eds. S. Schreiber, A. Stimpfle, Pustet, Regensburg 2000, s. 103-120 (Biblische Untersuchungen, 29); E. Schweitzer, The Good News According to Luke, trans. D. E. Green, John Knox Press, Atlanta 1984, s. 103; R. H. Fuller, The Formation of the Resurrection Narratives, wyd. 2, Fortress Press, Philadelphia 1980, s. 147-152, 160-161; F. Neirynck, John 21, „New Testament Studies” 36 (1990) nr 3, s. 321-336, https://doi. org/10.1017/S0028688500015770.

70 Por. B. Żychlińska, Liczba trzy w Tradycji Łukaszowej, „Ruch Biblijny i Liturgiczny” 54 (2001) nr 4, s. 295-302, https://doi.org/10.21906/rbl.3580.

71 Zob. próby ustalenia tożsamości tego ucznia: C. E. Hill, The Identity of John's Nathanael, „Journal for the Study of the New Testament” 20 (1998) nr 67, s. 45-61, https://doi.org/10.1177/ 0142064X9802006703; U. Holzmeister, Nathanael fuitne idem ac S. Bartholomaeus Apostolus?, „Biblica” 21 (1940) nr 1, s. 28-39, http://www.jstor.org/stable/42631696; K. Hanhart, The Structure of John I 35 - IV 54, s. 22-46, [w:] Studies in John. Presented to Professor Dr. J. N. Sevenster on the Occasion of his Seventieth Birthday, ed. W. C. van Unnik, Brill 1970 (Novum Testamentum. Supplements, 24), https://doi.org/10.1163/9789004266018_004; zob. także C. Knights, Nathanael 
(3) skrybowie włączyli do tekstu właściwego, który wymieniał pięciu uczniów z imienia (Piotra, Jakuba, Jana, Tomasza Didymosa i Natanaela), wzmiankę o dwóch innych uczniach, którzy stanowili marginalną glosę (drugi wzór Janowy 5+2).

Liczba uczniów w J 21, 2 powstała zatem w wyniku procesu, który można przedstawić jako 3+2+2. W dalszej części artykułu okaże się, że spostrzeżenie to nie jest bezzasadne. Co ciekawe, apokaliptyczne trzęsienia ziemi, które zostały rozmieszczone według wzorów Janowych ${ }^{72}$, skomponowane są także według porządku $3+2+2$ :

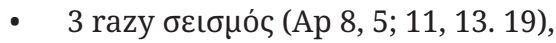

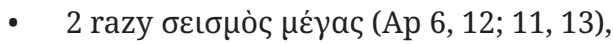

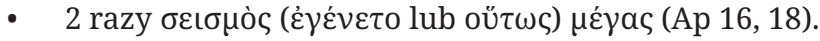

Nowa interpretacja liczby 153 w J 21, 11 odsłania jej ścisły związek z jednością całej Ewangelii Jana, rzucając nowe światło na problem struktury literackiej czwartej Ewangelii ${ }^{73}$ - jest wartością numeryczną greckiego wyrażenia

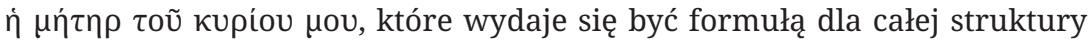
Ewangelii Jana ${ }^{74}$ :

\begin{tabular}{|c|c|}
\hline$\dot{\eta}$ & J $1,1-\mathrm{J} 1,51$ \\
\hline$\mu \eta ́ \tau \eta \rho$ & Cud w Kanie Galilejskiej (J 2, 1-12) \\
\hline$\tau 0 \tilde{}$ & $\mathrm{J} 2,13-\mathrm{J} 19,24$ \\
\hline kupíou & Testament z krzyża (J 19, 25-27) \\
\hline$\mu \mathrm{ov}$ & J 19, 28 - J 21, 25 \\
\hline
\end{tabular}

Cud w Kanie Galilejskiej i testament z krzyża są kluczowymi perykopami - dwukrotnie pojawia się Maryja w Ewangelii Jana: na weselu w Kanie Galilejskiej (J 2, 1-12) i pod krzyżem Jezusowym (J 19, 25-27) ${ }^{75}$. Jezus zwraca

and Thomas: Two Objectors, Two Confessors - Reading John 20:24-29 and John 1:44-51 in Parallel, „The Expository Times” 125 (2014) nr 7, s. 328-332, https://doi.org/10.1177/0014524613494051.

72 Zob. P. M. Mucha, Matka Pana a apokaliptyczne trzęsienia ziemi, „,Ruch Biblijny i Liturgiczny” 71 (2018) nr 4, s. 364-365, https://doi.org/10.21906/rbl.3623.

73 Por. S. Mędala, Problem struktury literackiej czwartej Ewangelii, „Ruch Biblijny i Liturgiczny” 46 (1993) nr 1, s. 11-17, https://doi.org/10.21906/rbl.1020.

74 P. M. Mucha, What was the Origin of Number 153?, „Ruch Biblijny i Liturgiczny” 66 (2013) nr 2, s. 112-114, https://doi.org/10.21906/rbl.62.

75 M. Czajkowski, Maryja u progu i kresu dzieła Mesjasza (J 2, 1-11 i 19, 25-27), [w:] Egzegeza Ewangelii św. Jana. Kluczowe teksty i tematy teologiczne, red. F. Gryglewicz, wyd. 2, Katolicki Uniwersytet Lubelski Redakcja Wydawnictw, Lublin 1992, s. 27-40; por. także A. Nalewaj, Analiza porównawcza struktury literackiej i motywów teologicznych w J 2, 1-12 i 20, 1-18, „Studia Warmińskie” 49 (2012), s. 107-121, https://doi.org/10.31648/sw.257. Zob. W. Smereka, Ecce Mater Tua, „Ruch Biblijny i Liturgiczny" 9 (1956) nr 4-6, s. 244-261, https://doi.org/10.21906/rbl.2590; T. Borkowska, 
się w nich do Maryi dostojnym tytułem „Niewiasta”76. Sam zatem podkreśla Jej godność, co świetnie odpowiada tej nowej interpretacji liczby 153 w J 21, 11.

\section{Struktura Modlitwy Pańskiej w świetle wzorów Janowych}

Wzory Janowe rzucają zupełnie nowe światło na budowę Modlitwy Pańskiej. Łukaszowy Pater noster składa się z pięciu próśb. Z tylu słów składa się greckie

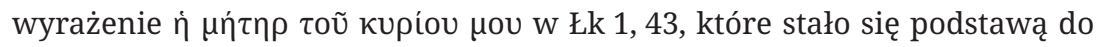
podkreślania godności Maryi jako Matki Pana. Co więcej, Łukaszowa wersja Modlitwy Pańskiej (Łk 11, 2b-4) zawiera trzy prośby dotyczące ludzkich potrzeb i spraw oraz dwie prośby skierowane do Boga, co odzwierciedla pierwszy wzór Janowy 3+277:

Dwie prośby skierowane do Boga

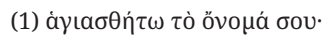

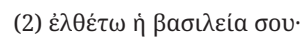

Trzy prośby odnoszące się do ludzkich potrzeb i spraw

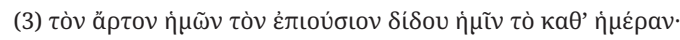

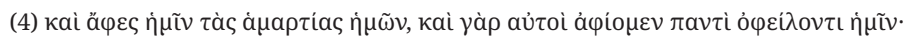

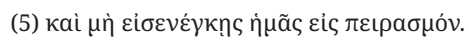

Rola Maryi w J 2, 1-12, „Colloquia Theologica Ottoniana” 1 (2018), s. 7-22, https://doi.org/10.18276/ cto.2018.1-01; F. C. Burkitt, ‘Woman, What Have I To Do With Thee?', „The Journal of Theological Studies” 13 (1912) nr 52, s. 594-595, https://doi.org/10.1093/jts/os-XIII.52.594; R. F. Collins, Cana (Jn. 2:1-12) - The first of his signs or the key to his signs?, „Irish Theological Quarterly” 47 (1980) nr 2, s. 79-95, https://doi.org/10.1177/002114008004700201; C. P. Ceroke, Jesus and Mary at Cana: Separation or Association?, „Theological Studies” 17 (1956) nr 1, s. 1-38, https://doi. org/10.1177/004056395601700101; J.-B. M. Bulembat, Head-Waiter and Bridegroom of the Wedding at Cana: Structure and Meaning of John 2.1-12, „Journal for the Study of the New Testament” 30 (2007) nr 1, s. 55-73, https://doi.org/10.1177/0142064X07081546.

76 A. Nalewaj, „Matka Jezusa” $i$,Niewiasta” jako tytuły Maryi w czwartej Ewangelii, „Ruch Biblijny i Liturgiczny” 63 (2010) nr 1, s. 13-30, https://doi.org/10.21906/rbl.158; T. Langkammer, Jn 2, 4 w świetle najnowszej egzegezy, „Ruch Biblijny i Liturgiczny” 15 (1962) nr 2, s. 82-91, https://doi. org/10.21906/rbl.2864; B. Zbroja, Teologia wypowiedzi Jezusa z krzyża, „Ruch Biblijny i Liturgiczny” 65 (2012) nr 3, s. 218-220, https://doi.org/10.21906/rbl.94.

77 Tekst grecki Nowego Testamentu w tym artykule za: Novum Testamentum Graece, begründet von E. und E. Nestle, hrsg. von B. und K. Aland, J. Karavidopoulos, C. M. Martini, B. M. Metzger, wyd. 28, Deutsche Bibelgesellschaft, Stuttgart 2012. 
Mateuszowy Ojcze nasz (Mt 6, 9-13) składa się z siedmiu próśb: z pięciu próśb Łukaszowych oraz dwóch dodatkowych, których nie ma Łukasz. Został tutaj więc zastosowany drugi wzór Janowy 5+2:

Pięć próśb z Ewangelii Łukasza i dwie dodatkowe prośby

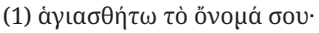

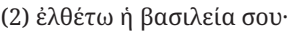

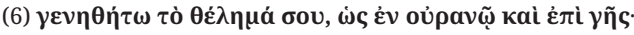

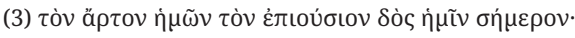

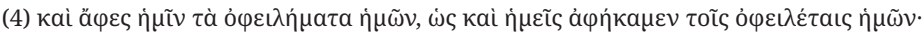

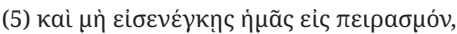

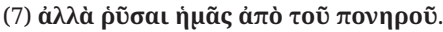

Warto zauważyć, że dwie dodatkowe prośby w Ewangelii Mateusza, których nie ma u Łukasza, są dodane do próśb Łukaszowych na końcu każdej z obu sekcji. Mateusz nie wstawił tych dwóch próśb w dowolnym miejscu, lecz jedną prośbę dodał na końcu sekcji skierowanej do Boga, gdyż do Niego się odnosi, oraz jedną prośbę na końcu sekcji odnoszącej się do ludzkich potrzeb i spraw.

Jak zostało wcześniej wspomniane, niektórzy uważają, że Pater noster składa się z sześciu próśb. Jeśli Ojcze nasz składałby się z sześciu próśb, to także podział tej modlitwy na dwa tryptyki zawierające po trzy prośby wynikałby z użycia pierwszego wzoru Janowego 3+2:

Trzy prośby skierowane do Boga

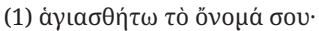

(2) $\dot{\varepsilon} \lambda \theta \dot{\varepsilon} \tau \omega \dot{\eta ் ~} \beta a \sigma 1 \lambda \varepsilon i ́ a \sigma o v$.

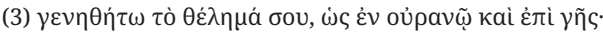

Trzy prośby odnoszące się do ludzkich potrzeb i spraw

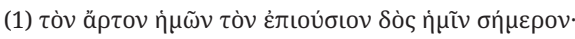

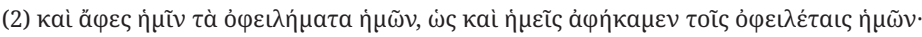

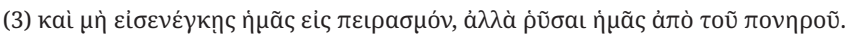


Modlitwa Pańska była zatem skomponowana według wzorów Janowych zarówno przez Łukasza, jak i Mateusza niezależnie od przyjętego podziału próśb w tej modlitwie. Oznacza to, że budowa Modlitwy Pańskiej jest mariologiczna. Ojcze nasz został więc zarówno przez Łukasza, jak i Mateusza ściśle związany z Matką Pana.

Chociaż podział Modlitwy Pańskiej na dwa tryptyki da się wyjaśnić za pomocą wzoru Janowego 3+2, to jednak taka budowa nie jest uzasadniona. Mateuszowa Modlitwa Pańska składa się wyraźnie z siedmiu próśb ${ }^{78}$, a Łukaszowa z pięciu. Takie liczby próśb w tej modlitwie wydają się być bronione przez cudowne rozmnożenia chleba. W Ewangeliach są dwa cuda, w których Jezus rozmnożył chleb: pierwszy opisany jest przez wszystkich ewangelistów (Mt 14, 13-21; Mk 6, 31-44; Łk 9, 12-17; J 6, 1-14); drugi znajduje się tylko u Mateusza i Marka (Mt 15, 32-39; Mk 8, 1-9) ${ }^{79}$. Opowiadanie Łukasza różni się istotnie od Mateuszowych ${ }^{80}$, a pewna cecha ujawnia się wyraźnie:

- u Łukasza jest tylko pierwsze rozmnożenie chleba (Łk 9, 12-17), w którym Jezus posłużył się pięcioma chlebami, czyli tą samą liczbą, która jest liczbą próśb w Łukaszowym Ojcze nasz.

78 Katechizm Kościoła katolickiego, 2803-2854.

79 Zob. np. S. A. Hunt, Rewriting the Feeding of Five Thousand: John 6.1-15 as a Test Case for Johannine Dependence on the Synoptic Gospels, Peter Lang, New York-Bern-Berlin-Bruxelles-Frankfurt am Main-Oxford-Wien 2011 (Studies in Biblical Literature, 125), https://doi.org/10.3726/978-1-45390153-3; A. M. Farrer, Loaves and Thousands, „The Journal of Theological Studies” 4 (1953) nr 1, s. 1-14, https://doi.org/10.1093/jts/IV.1.1; J. Knackstedt, Die beiden Brotvermehrungen im Evangelium, „New Testament Studies” 10 (1964) nr 3, s. 309-335, https://doi.org/10.1017/S0028688500024231; B. Van Iersel, Die wunderbare Speisung und das Abendmahl in der synoptischen Tradition (Mk VI 35-44 par., VIII 1-20 par.), „Novum Testamentum” 7 (1964) nr 3, s. 167-194, https://doi. org/10.2307/1560311; G. Ziener, Das Brotwunder im Markusevangelium, „Biblische Zeitschrift” 4 (1960), s. 282-285; J. R. C. Cousland, The Feeding of the Four Thousand Gentiles in Matthew? Matthew 15:29-39 as a Test Case, „Novum Testamentum” 41 (1999) nr 1, s. 1-23, https://doi. org/10.1163/156853699323281883; H. Montefiore, Revolt in the Desert?, „New Testament Studies” 8 (1962) nr 2, s. 135-141, https://doi.org/10.1017/S0028688500005890; G. H. Boobyer, The Eucharistic Interpretation of the Miracles of the Loaves in St. Mark's Gospel, „The Journal of Theological Studies” 3 (1952) nr 2, s. 161-171, https://doi.org/10.1093/jts/III.2.161; I. Buse, The Gospel Accounts of the Feeding of the Multitudes, „The Expository Times” 74 (1963) nr 6, s. 167-170, https://doi. org/10.1177/001452466307400603; E. Bammel, The Feeding of the Multitude, [w:] Jesus and the Politics of his Day, eds. E. Bammel, C. F. D. Moule, Cambridge University Press, Cambridge 2010, s. 211-240, https://doi.org/10.1017/CBO9780511554834.014.

80 Por. W. C. K. Poon, Superabundant Table Fellowship in the Kingdom: The Feeding of the Five Thousand and the Meal Motif in Luke, „The Expository Times” 114 (2003) nr 7, s. 224-230, https:// doi.org/10.1177/001452460311400703. 
- u Mateusza oprócz pierwszego jest także drugie rozmnożenie chleba (Mt 15, 32-39), w którym Jezus posłużył się siedmioma chlebami, czyli liczbą, która jest liczbą próśb w Mateuszowym Ojcze nasz.

Co więcej, w pierwszym rozmnożeniu chleba jest pięć chlebów i dwie ryby (drugi wzór Janowy 5+2), a w drugim rozmnożeniu nie ma podanej dokładnej liczby ryb, tylko liczba chlebów - siedem chlebów to jest przecież suma pięciu chlebów oraz dwóch chlebów (drugi wzór Janowy 5+2). Uderzające podobieństwo wydaje się potwierdzać, że Łukaszowy Ojcze nasz składa się z pięciu próśb, a Mateuszowy z siedmiu. Modlitwa Pańska została zatem zarówno w wersji Mateuszowej, jaki i Łukaszowej skomponowana według wzorów Janowych. Spostrzeżenie to prowadzi do kilku ciekawych i ważnych wniosków.

\section{Konkluzje}

W świetle wzorów Janowych powstanie Modlitwy Pańskiej przebiegało w dwóch etapach:

(1) Łukasz skomponował swoją wersję Ojcze nasz według pierwszego modelu Janowego 3+2 z trzech próśb dotyczących ludzkich potrzeb i spraw oraz dwóch próśb odnoszących się do Boga.

(2) Mateusz przejął Łukaszowy Ojcze nasz składający się z pięciu próśb i dodał do nich dwie inne, stosując w ten sposób drugi model Janowy $5+2$.

W świetle wzorów Janowych Mateuszowy Ojcze nasz nie pochodzi bezpośrednio od samego Jezusa, lecz jest Łukaszową wersją przejętą i uzupełnioną przez Mateusza. Nie wyklucza to jednak, że poszczególne prośby mogą pochodzić bezpośrednio od Jezusa ${ }^{81}$. Co ciekawe, niektórzy uważają, że pierwotnie Pater noster składał się tylko z trzech próśb, które dotyczyły ludzkich spraw i potrzeb ${ }^{82}$. Jeśli pierwotny Pater noster rzeczywiście istniał i składał się tylko z trzech próśb, to powstanie Modlitwy Pańskiej przebiegało w trzech etapach:

81 Por. J. C. O’Neill, The Lord's Prayer, „Journal for the Study of the New Testament” 16 (1993) nr 51, s. 3-25, https://doi.org/10.1177/0142064X9301605101.

82 Np. E. Von Dobschütz, The Lord's Prayer, „Harvard Theological Review” 7 (1914) nr 3, s. 296-297, https://doi.org/10.1017/S0017816000011433; G. Klein, Die ursprüngliche Gestalt des Vaterunsers, „Zeitschrift für die Neutestamentliche Wissenschaft und die Kunde der Älteren Kirche” 7 (2009) nr 1, s. 35, https://doi.org/10.1515/zntw.1906.7.1.34; I. Abrahams, Studies in Pharisaism and the Gospels, t. 2, Cambridge University Press, Cambridge 1924, s. 100. 
(1) Istnienie przedkanonicznego Ojcze nasz składającego się tylko z trzech próśb:

[1] Chleba naszego powszedniego daj nam dzisiaj;

[2] I przebacz nam nasze winy, jak i my przebaczamy tym, którzy przeciw nam zawinili;

[3] I nie dopuść, abyśmy ulegli pokusie.

(2) Przejęcie przez Łukasza pierwotnego Pater noster składającego się $\mathrm{z}$ trzech próśb i dodanie do nich dwóch próśb odnoszących się do Boga (pierwszy wzór Janowy 3+2):

[4] Niech się święci Twoje imię;

[5] Niech przyjdzie Twoje królestwo!

[1] Naszego chleba powszedniego dawaj nam na każdy dzień;

[2] I przebacz nam nasze grzechy, bo i my przebaczamy każdemu, kto nam zawini;

[3] I nie dopuść, byśmy ulegli pokusie.

(3) Przejęcie przez Mateusza Łukaszowego Pater noster składającego się z pięciu próśb i dodanie do nich dwóch innych (drugi wzór Janowy 5+2):

[4] Niech się święci imię Twoje;

[5] Niech przyjdzie królestwo Twoje!

[6] Niech Twoja wola spełnia się na ziemi, tak jak i w niebie.

[1] Chleba naszego powszedniego daj nam dzisiaj;

[2] I przebacz nam nasze winy, jak i my przebaczamy tym, którzy przeciw nam zawinili;

[3] I nie dopuść, abyśmy ulegli pokusie,

[7] Ale nas zachowaj od złego!

Cały proces kompozycji Modlitwy Pańskiej przebiegał zatem według formuły 3+2+2. W drugim punkcie niniejszego artykułu zostało pokazane, że według tego modelu zmieniała się także liczba uczniów biorących udział w obfitym połowie ryb (Łk 5, 1-11; j 21, 1-8). Nie był to więc żaden przypadek.

Wykorzystanie przez Mateusza i Łukasza wzorów Janowych w Modlitwie Pańskiej rzuca nowe światło na problem synoptyczny. Mateusz znał Ewangelię Łukasza i Łukaszową wersję Modlitwy Pańskiej wykorzystał w swojej Ewangelii. Nie korzystał zatem ze źródła Q, lecz bezpośrednio z Ewangelii 
Łukasza $^{83}$. Ten logiczny wniosek stoi w sprzeczności z powszechnie przyjmowanymi rozwiązaniami problemu synoptycznego ${ }^{84}$.

Bezpośrednia zależność Mateusza od Ewangelii Łukasza może zaskakiwać, ale jeszcze bardziej dziwi, że ta zależność jest zbieżna z kolejnością tych dwóch Ewangelii otrzymaną w wyniku tzw. hipertekstualnej interpretacji powstania Ewangelii kanonicznych ${ }^{85}$. Wątpliwe jest, by Ewangelie były owocem systematycznego, sekwencyjnego i hipertekstualnego opracowania Listów Pawłowych ${ }^{86}$, ale obecność wzorów Janowych zarówno w Mateuszowej, jak i Łukaszowej Modlitwie Pańskiej dowodzi, że Mateusz znał Ewangelię Łukasza i jego Ojcze nasz rozszerzył o dwie dodatkowe prośby zgodnie z drugim wzorem Janowym 5+2. Odkrycie zatem wzorów Janowych zarówno w Mateuszowej, jak i Łukaszowej Modlitwie Pańskiej broni pierwszeństwa

83 Por. A. Paciorek, $Q$ - Ewangelia Galilejska, Towarzystwo Naukowe Katolickiego Uniwersytetu Lubelskiego, Lublin 2001, s. 295-297 (Źródła i Monografie, 221); S. Carruth, S. D. Anderson, A. Garsky, Q 11:2b-4, Peeters, Leuven 1996 (Documenta Q).

84 Zob. np. B. Adamczewski, $Q$ or not $Q$ ? The So-Called Triple, Double, and Single Traditions in the Synoptic Gospels, Peter Lang, Frankfurt am Main-Berlin-Bern-Bruxelles-New York-Oxford-Wien 2010, s. 19-186, https://doi.org/10.3726/978-3-653-00190-7; R. Bartnicki, Najnowsze rozwiazania problemu synoptycznego, „Ruch Biblijny i Liturgiczny” 42 (1989) nr 1, s. 28-41, https://doi. org/10.21906/rbl.2020; R. Bartnicki, Problem synoptyczny dawniej i dzisiaj, „Studia Theologica Varsaviensia” 27 (1989) nr 1, s. 15-73.

85 Zob. B. Adamczewski, $Q$ or not Q? The So-Called Triple, Double, and Single Traditions in the Synoptic Gospels, Peter Lang, Frankfurt am Main-Berlin-Bern-Bruxelles-New York-Oxford-Wien 2010, https://doi.org/10.3726/978-3-653-00190-7; B. Adamczewski, The Gospel of Matthew. A Hypertextual Commentary, Peter Lang, Frankfurt am Main-Bern-Bruxelles-New York-Oxford-WarszawaWien 2017, https://doi.org/10.3726/b10799; B. Adamczewski, The Gospel of Luke. A Hypertextual Commentary, Peter Lang, Frankfurt am Main-Berlin-Bern-Bruxelles-New York-Oxford-Wien 2016, https://doi.org/10.3726/978-3-653-06278-6.

86 R. B. Vinson, $Q$ or not $Q$ ? The So-Called Triple, Double, and Single Traditions in the Synoptic Gospels by Bartosz Adamczewski, "The Catholic Biblical Quarterly” 74 (2012) nr 1, s. 141-142, http:// www.jstor.org/stable/43727932; P. Foster, Review Article: Q or Not Q?: A Self-deluded Attempt to Solve the Synoptic Problem, „The Expository Times” 122 (2011) nr 4, s. 177-180, https://doi. org/10.1177/0014524610384325; T. E. Phillips, Q or Not Q? The So-Called Triple, Double, and Single Traditions in the Synoptic Gospels - by Bartosz Adamczewski, „Religious Studies Review” 37 (2011) nr 2, s. 130, https://doi.org/10.1111/j.1748-0922.2011.01513_7.x; E. Lipiński, Q or not Q? The So-Called Triple, Double, and Single Traditions in the Synoptic Gospels, „The Polish Journal of Biblical Research” 10 (2011) nr 1-2, s. 164-165; A. Malina, Bartosz Adamczewski, Q or not Q? The So-Called Triple, Double, and Single Traditions in the Synoptic Gospels, Peter lang, Frankfurt am Main-Berlin-Bruxelles-New York-Oxford-Wien 2010, 554 s., „Śląskie Studia HistorycznoTeologiczne” 46 (2013) nr 2, s. 468-479. 
Ewangelii Łukasza przed Mateuszową, co jest proponowane tylko przez niektórych uczonych ${ }^{87}$. Oznacza to także odrzucenie istnienia źródła $\mathrm{Q}^{88}$.

Łukasz nie skrócił Mateuszowej wersji Ojcze nasz ${ }^{89}$, a zatem i nie przeredagował Mateuszowego Kazania na Górze ${ }^{90}$. Zgadza się to z niemal powszechnym przekonaniem egzegetów ostatnich dwóch stuleci, którzy wersję krótszą uważali za starszą. Trudno sobie zresztą wyobrazić, by Łukasz usuwał jakiekolwiek istotne części tekstu z tak ważnej modlitwy Jezusa ${ }^{91}$. Co więcej, obecność wzorów Janowych w Modlitwie Pańskiej podważa pogląd, że Łukaszowa wersja Ojcze nasz mogła pochodzić z greckich Kościołów, a wersja Mateuszowa mogła powstać w środowisku aramejskim bądź syryjskim ${ }^{92}$.

Dwie wersje Modlitwy Pańskiej nie są zatem dwiema różnymi, choć podobnymi do siebie modlitwami ${ }^{93}$, lecz Mateuszowa jest przeredagowaną wersją Łukaszowej. Wersją pierwotną jest zatem wersja z Ewangelii Łukasza i ta właśnie powinna być wyjściem do rozważań ${ }^{94}$. Trzeba także pamiętać, że trzecia

87 Np. R. Huggins, Matthean Posteriority: A Preliminary Proposal, „Novum Testamentum” 34 (1992) nr 1, s. 1-22, https://doi.org/10.1163/156853692X00131; M. Hengel, Die vier Evangelien und das eine Evangelium von Jesus Christus. Studien zu ihrer Sammlung und Entstehung, Mohr Siebeck, Tübingen 2008; C. G. Wilke, Der Urevangelist oder exegetisch kritische Untersuchung über das Verwandtschaftsverhältniss der drei ersten Evangelien, Gerhard Fleischer, Dresden-Leipzig 1838; L. William, The Origin of the Gospels, „The Church Quarterly Review” 94 (1922), s. 216-239.

88 Por. np. P. Foster, Is It Possible to Dispense with Q?, „Novum Testamentum” 45 (2003) nr 4, s. 313337, https://doi.org/10.1163/156853603322538730; A. Farrer, On Dispensing with Q, [w:] Studies in the Gospels: Essays in Memory of R. H. Lightfoot, ed. D. E. Nineham, Blackwell, Oxford 1955, s. 55-88; M. S. Goodacre, The synoptic problem: a way through the maze, Sheffield Academic Press, London-New York 2001; M. S. Goodacre, The Case Against Q: Studies in Markan Priority and the Synoptic Tradition, Trinity Press International, Harrisburg 2002; M. D. Goulder, Luke: a new paradigm, t. 1-2, Sheffield 1989.

89 Por. M. D. Goulder, The Composition of the Lord's Prayer, „The Journal of Theological Studies” 14 (1963) nr 1, s. 32-45, https://doi.org/10.1093/jts/XIV.1.32.

90 Por. A. Kowalczyk, Łukasz przeredagował Mateuszowi Kazanie na Górze, „Studia Gdańskie” 15-16 (2002-2003), s. 27-39.

91 F. Mickiewicz, Ewangelia według św. Łukasza, dz. cyt., cz. 1, s. 577-578.

92 Por. R. E. Brown, The Pater Noster as an Eschatological Prayer, [in:] New Testament Essays, ed. R. E. Brown, The Bruce Publishing Company, Milwaukee 1965, s. 200; R. E. Brown, The Pater Noster as an Eschatological Prayer, „Theological Studies” 22 (1961) nr 2, s. 175-208, https://doi. org/10.1177/004056396102200201.

93 Por. L. Mateja, Dwie wersje Modlitwy Pańskiej odczytane w kluczu inicjacyjnym, „Vox Patrum” 67 (2017), s. 389-401, https://doi.org/10.31743/vp.3406.

94 Zob. np. R. Leaney, The Lucan Text of the Lord's Prayer (Lk XI 2-4), „Novum Testamentum” 1 (1957) nr 1, s. 103-111, https://doi.org/10.1163/156853685X00571; P. Edmonds, The Lucan Our Father: A Summary of Luke's Teaching on Prayer?, „The Expository Times” 91 (1980) nr 5, s. 140-143, 
Ewangelia kanoniczna była jedyną, którą uznawał Marcjon ${ }^{95}$ - człowiek, który odegrał niemałą rolę w chrześcijaństwie w II wieku ${ }^{96}$. Dlatego sensownym jest badanie tekstu Modlitwy Pańskiej w Ewangelii Marcjona ${ }^{97}$, zwłaszcza że niektórzy uważają, iż to Ewangelia Marcjona była źródłem dla Łukasza ${ }^{98}$.

W świetle wzorów Janowych próby rekonstrukcji pierwotnej formy Modlitwy Pańskiej w oparciu o synoptyczny układ Ewangelii Mateusza i Łukasza są bezzasadne ${ }^{99}$. Co więcej, cuda rozmnożenia chleba potwierdzają zależność Mateusza od Ewangelii Łukasza ${ }^{100}$. W świetle wzorów Janowych trudno mówić o dwóch historycznych wydarzeniach rozmnożenia chleba, które pochodzą z różnych tradycji ${ }^{101}$, lecz drugie rozmnożenie chleba jest

https://doi.org/10.1177/001452468009100504; J. Flis, Struktura i treść krótszej wersji modlitwy „Ojcze nasz” (Ek 11, 2b-4), „Colloquia Theologica Ottoniana” 2 (2013), s. 21-41.

95 Zob. Tertulian, Adversus Marcionem.

96 J. M. Lieu, Marcion and the Making of a Heretic. God and Scripture in the Second Century, Cambridge University Press, Cambridge 2015, https://doi.org/10.1017/CBO9781139245876; S. Moll, The Arch-Heretic Marcion, Mohr Siebeck, Tübingen 2010 (Wissenschaftliche Untersuchungen zum Neuen Testament, 250), https://doi.org/10.1628/978-3-16-151539-2; P. Foster, Marcion: His Life, Works, Beliefs, and Impact, „The Expository Times” 121 (2010) nr 6, s. 269-280, https://doi. org/10.1177/0014524609357509.

97 D. Roth, The Text of the Lord's Prayer in Marcion's Gospel, „Zeitschrift für die Neutestamentliche Wissenschaft und die Kunde der älteren Kirche” 103 (2012) nr 1, s. 47-63, https://doi.org/10.1515/ znw-2012-0003.

98 Zob. np. M. Klinghardt, Markion vs. Lukas: Plädoyer für die Wiederaufnahme eines alten Falles, „New Testament Studies” 52 (2006) nr 4, s. 484-513, https://doi.org/10.1017/S0028688506000270; M. Klinghardt, The Marcionite Gospel and the Synoptic Problem: A New Suggestion, „Novum Testamentum” 50 (2008) nr 1, s. 1-27, https://doi.org/10.1163/156853608X257527. Zob. także J. B. Tyson, Marcion and Luke-Acts. A Defining Struggle, University of South Carolina Press, Columbia 2006; C. B. Waite, History of the Christian Religion to the Year Two Hundred, C. V. Waite, Chicago 1881; D. Roth, Marcion's Gospel and Luke: The History of Research in Current Debate, „Journal of Biblical Literature” 127 (2008) nr 3, s. 513-527, https://doi.org/10.2307/25610137.

99 Por. np. B. Heininger, Die Inkulturation des Christentums: Aufsätze und Studien zum Neuen Testament und seiner Umwelt, Mohr Siebeck, Tübingen 2010, s. 5-8 (Wissenschaftliche Untersuchungen zum Neuen Testament, 255), https://doi.org/10.1628/978-3-16-151544-6.

100 Por. F. Neirynck, Response to the Multiple Stage Hypothesis, I: The Introduction to the Feeding Story, [w:] The Interrelation of the Gospels: A Symposium Led by M.E. Boismard, WR. Framer, F. Neirynck, Jerusalem 1984, ed. D. L. Dungan, Louvain University Press, Louvain 1990, s. 81-93; W. R. Stegner, Lukan Priority in the Feeding of the Five Thousand, „Chicago Society of Biblical Research” 21 (1976), s. 19-28.

101 Por. J. Knackstedt, Die beiden Brotvermehrungen im Evangelium, „New Testament Studies” 10 (1964) nr 3, s. 309-335, https://doi.org/10.1017/S0028688500024231. 
przeredagowanym dubletem pierwszego ${ }^{102}$, tak jak Mateuszowy Ojcze nasz jest przeredagowaną wersją Łukaszowego.

Podsumowując, Modlitwa Pańska została skomponowana w dwóch głównych etapach: najpierw przez Łukasza według pierwszego wzoru Janowego 3+2 (Łk 11, 2b-4), a potem - w oparciu o istniejącą już wersję w Ewangelii Łukasza - przez Mateusza według drugiego wzoru Janowego 5+2 (Mt 6, 9-13). Kompozycja Modlitwy Pańskiej była zatem zarówno u Łukasza, jak i u Mateusza powiązana z Matką Pana. Wzory Janowe odsłaniają jej mariologiczny charakter, do tej pory zupełnie nieznany.

\section{Abstrakt}

\section{Modlitwa Pańska w świetle wzorów Janowych}

Wzory Janowe, które ujawniają godność Maryi jako „Matki Pana”, rzucają nowe światło na Modlitwę Pańską. Łukaszowy Ojcze nasz zawiera trzy prośby dotyczące ludzkich potrzeb i dwie prośby skierowane do Boga, co odzwierciedla pierwszy wzór Janowy 3+2. Mateuszowy Pater noster składa się z pięciu Łukaszowych próśb i dwóch dodatkowych próśb, które występują tylko w Ewangelii Mateusza. Odpowiada to drugiemu wzorowi Janowemu 5+2. W świetle modeli Janowych Łukaszowy Ojcze nasz był wykorzystany przez Mateusza, który uzupełnił wersję Łukaszową.

Słowa kluczowe: Modlitwa Pańska, Ojcze nasz, Jan Ewangelista

\section{Abstract}

\section{The Lord's Prayer in Light of the Johannine Models}

The Johannine models, which present Mary's dignity as the "Mother of God," shed new light on the Lord's prayer. Luke's Our Father contains three requests concerning human needs and two requests directed towards God, which is reflected in the first Johannine model 3+2. Matthew's Pater poster consists of five requests from Luke and two additional requests that only appear in the Gospel of Matthew. This corresponds to the second Johannine model 5+2. In light of the Johannine models, "Our Father" was used by Matthew, who supplemented Luke's version.

Keywords: Lord's prayer, Our Father, John the Evangelist

102 Por. B. van Iersel, Die wunderbare Speisung und das Abendmahl in der synoptischen Tradition (Mk VI 35-44 par., VIII 1-20 par.), „Novum Testamentum” 7 (1964) nr 3, s. 167-194, https://doi. org/10.2307/1560311; G. Ziener, Das Brotwunder im Markusevangelium, „Biblische Zeitschrift” 4 (1960), s. 282-285. 


\section{References}

Ackroyd, P. R. (1959). The 153 Fishes in John XXI. 11 - A Further Note. The Journal of Theological Studies, 10(1), 94-94. https://doi.org/10.1093/jts/X.1.94

Adamczewski, B. (2010). Q or not Q? Peter Lang. https://doi.org/10.3726/978-3-653-00190-7

Adamczewski, B. (2016). The Gospel of Luke. Peter Lang. https://doi.org/10.3726/978-3-653-06278-6

Adamczewski, B. (2017). The Gospel of Matthew. Peter Lang. https://doi.org/10.3726/b10799

Aland, B., Aland, K., Karavidopoulos, J., Martini, C. M., Metzger, B. M., \& Strutwolf, H. (Eds.). (2012). Novum Testamentum Graece (E. Nestle \& E. Nestle, Trans.; 28th ed.). Deutsche Bibelgesellschaft.

Ayo, N. (1992). The Lord's prayer. A survey theological and literary. University of Notre Dame Press.

Bahr, G. J. (1965). The Use of the Lord's Prayer in the Primitive Church. Journal of Biblical Literature, 84(2), 153-159. https://doi.org/10.2307/3264137

Bammel, E. (1984). The Feeding of the Multitude. In E. Bammel \& C. F. D. Moule (Eds.), Jesus and the Politics of his Day (1st ed., pp. 211-240). Cambridge University Press. https://doi.org/10.1017/CB09780511554834.014

Barr, J. (1988). 'Abbā isn’t ‘daddy.' The Journal of Theological Studies, 39(1), 28-47. https://doi.org/10.1093/jts/39.1.28

Bartnicki, R. (1989). Najnowsze rozwiązania problemu synoptycznego. Ruch Biblijny i Liturgiczny, 42(1), 28-41. https://doi.org/10.21906/rbl.2020

Bauckham, R. (2002). The 153 Fish and the Unity of the Fourth Gospel. Neotestamentica, 36(1-2), 77-88.

Bednarz, M. (1999). Ojcze nasz. Biblos.

Bernard, J. H., \& McNeile, A. H. (1928). The international critical commentary. A critical and exegetical commentary on the Gospel According to St. John (Vol. 2). T. \& T. Clark.

Blaskovic, G. (2001). Die Erzählung vom reichen Fischfang (Lk 5,1-11; Joh 21,1-14). Wie Johannes eine Erzählung aus dem Lukasevangelium für seine Zwecke umschreibt. In S. Schreiber \& H. Leroy (Eds.), Johannes aenigmaticus Studien zum Johannesevangelium für Herbert Leroy (pp. 103-120). Pustet.

Blumenthal, C. (2017). ,... wie im Himmel so auf Erden“ Die räumlichen Implikationen der Vergebungsbitte des matthäischen Vaterunsers. Zeitschrift Für Die Neutestamentliche Wissenschaft, 108(2), 191-211. https://doi. org/10.1515/znw-2017-0008

Bockmuehl, M. (2011). The Son of David and his Mother. The Journal of Theological Studies, 62(2), 476-493. https:// doi.org/10.1093/jts/flr101

Boobyer, G. H. (1952). The Eucharistic Interpretation of the Miracles of the Loaves in St. Mark's Gospel. The Journal of Theological Studies, 3(2), 161-171. https://doi.org/10.1093/jts/III.2.161

Borkowska, T. (2018). Rola Maryi w J 2, 1-12. Colloquia Theologica Ottoniana, 1, 7-22. https://doi.org/10.18276/ cto.2018.1-01

Bradley, M. C. (2007). Matthew. Poet, Historian, Dialectician. Peter Lang. https://doi.org/10.3726/978-1-4539-0694-1

Brooke, G. J. (1999). 4Q252 and the 153 Fish of John 21:11. In Antikes Judentum und Frühes ChristentumFestschrift für Hartmut Stegemann zum 65. Geburtstag. De Gruyter. https://doi.org/10.1515/9783110806069.253

Brown, M. J. (2000). „Panem Nostrum”: The Problem of Petition and the Lord’s Prayer. The Journal of Religion, 80(4), 595-614. https://doi.org/10.1086/490715

Brown, R. E. (1965). The Pater Noster as an Eschatological Prayer. In R. E. Brown (Ed.), New Testament Essays (pp. 175-208). The Bruce Publishing Company.

Brown, Raymond E. (1961). The Pater Noster as an Eschatological Prayer. Theological Studies, 22(2), 175-208. https://doi.org/10.1177/004056396102200201

Brown, Raymond Edward. (1970). The Gospel according to John (XIII-XXI). Doubleday.

Bulembat, J.-B. M. (2007). Head-Waiter and Bridegroom of the Wedding at Cana: Structure and Meaning of John 2.1-12. Journal for the Study of the New Testament, 30(1), 55-73. https://doi.org/10.1177/0142064X07081546

Burkitt, F. C. (1912). 'Woman, What Have I To Do With Thee?' The Journal of Theological Studies, 13(52), 594-595. https://doi.org/10.1093/jts/os-XIII.52.594 
Buse, I. (1963). The Gospel Accounts of the Feeding of the Multitudes. The Expository Times, 74(6), 167-170. https://doi.org/10.1177/001452466307400603

Carmignac, J. (1969). Recherches sur le « Notre Père ». Letouzey \& Ané.

Carmignac, J. (1978). Hebrew Translations of the Lord’s Prayer: A Historical Survey. In G. A. Tuttle (Ed.), Biblical and Near Eastern Studies. Essays in Honor of William Sanford LaSor (pp. 19-79). Eerdmans.

Carruth, S., Garsky, A., Anderson, S. D., Robinson, J. M., \& Carruth, S. (1996). Q 11:2b-4. Peeters.

Ceroke, C. P. (1956). Jesus and Mary at Cana: Separation or Association? Theological Studies, 17(1), 1-38. https:// doi.org/10.1177/004056395601700101

Clark, D. (2016). The Lord's Prayer. Origins and Early Interpretations. Brepols Publishers.

Collins, R. F. (1980). Cana (Jn. 2:1-12) - The first of his signs or the key to his signs? Irish Theological Quarterly, 47(2), 79-95. https://doi.org/10.1177/002114008004700201

Colson, F. H. (1915). Triangular Numbers in the New Testament. The Journal of Theological Studies, 16(10), 67-76. https://doi.org/10.1093/jts/os-XVI.10.67

Cousland, J. R. C. (1999). The Feeding of the Four Thousand Gentiles in Matthew? Matthew 15:29-39 as a Test Case. Novum Testamentum, 41(1), 1-23. https://doi.org/10.1163/156853699323281883

Culpepper, R. A. (2006). Designs for the Church in the Imagery of John 21:1-14. In J. Frey, J. G. Van der Watt, \& R. Zimmermann (Eds.), Imagery in the Gospel of John. Terms, forms, themes, and theology of Johannine figurative language (pp. 369-402). Mohr Siebeck.

Czajkowski, M. (1992). Maryja u progu i kresu dzieła Mesjasza (J 2, 1 -11 i 19, 25-27). In F. Gryglewicz (Ed.), Egzegeza Ewangelii św. Jana. Kluczowe teksty i tematy teologiczne (2nd ed., pp. 27-40). Katolicki Uniwersytet Lubelski Redakcja Wydawnictw.

Dąbek, T. M. (2000). Boże synostwo a ludzkie braterstwo Teologia wezwania Ojcze nasz. Ruch Biblijny i Liturgiczny, 53(3-4), 189-198. https://doi.org/10.21906/rbl.506

Drake, L. (2014). Did Jesus Oppose the prosbul in the Forgiveness Petition of the Lord's Prayer? Novum Testamentum, 56(3), 233-244. https://doi.org/10.1163/15685365-12341447

Drozd, J. (1983). Ojcze nasz. Modlitwa Pańska według wspótczesnej egzegezy. Księgarnia św. Jacka.

Edmonds, P. (1980). The Lucan Our Father: A Summary of Luke's Teaching on Prayer? The Expository Times, 91(5), 140-143. https://doi.org/10.1177/001452468009100504

Eisler, R. (1921). Orpheus, The fisher. Comparative studies in Orphic and early Christian cult symbolism. J. M. Watkins. Emerton, J. A. (1958). The Hundred And Fifty-Three Fishes in John XXI. 11. The Journal of Theological Studies, 9(1), 86-89. https://doi.org/10.1093/jts/IX.1.86

Emerton, J. A. (1960). Some New Testament Notes. The Journal of Theological Studies, 11(2), 329-336. https://doi. org/10.1093/jts/XI.2.329

Farrer, A. (1955). On Dispensing with Q. In D. E. Nineham (Ed.), Studies in the Gospels: Essays in Memory of R. H. Lightfoot (pp. 55-88). Blackwell.

Farrer, A. M. (1953). Loaves and Thousands. The Journal of Theological Studies, 4(1), 1-14. https://doi.org/10.1093/ jts/IV.1.1

Finkelstein, L. (1925). The Development of the Amidah. The Jewish Quarterly Review, 16(1), 1-43. https://doi. org/10.2307/1451747

Fitzmyer, J. A. (2003). And Lead Us Not into Temptation. Biblica, 84(2), 259-273. https://doi.org/10.2143/ BIB.84.2.3194471

Flis, J. (2004). Konkordancja Starego i Nowego Testamentu do Biblii Tysiaclecia (4th ed.). Vocatio.

Flis, J. (2013). Struktura i treść krótszej wersji modlitwy Ojcze nasz (Łk 11, 2b-4). Colloquia Theologica Ottoniana, 2, 21-41.

Foster, P. (2003). Is it Possible to Dispense with Q? Novum Testamentum, 45(4), 313-337. https://doi.org/10.1163/ 156853603322538730 
Foster, P. (2010). Marcion: His Life, Works, Beliefs, and Impact. The Expository Times, 121(6), 269-280. https://doi.org/10.1177/0014524609357509

Foster, P. (2011). Review Article: Q or Not Q?: A Self-deluded Attempt to Solve the Synoptic Problem. The Expository Times, 122(4), 177-180. https://doi.org/10.1177/0014524610384325

France, R. T. (2007). The Gospel of Matthew. William B. Eerdmans Publishing Company.

Freudenberger, R. (1969). Zum Text Der Zweiten Vaterunserbitte. New Testament Studies, 15(4), 419-432. https:// doi.org/10.1017/S0028688500019263

Fuller, R. H. (1980). The formation of the Resurrection narratives (2nd ed.). Fortress Press.

Garland, D. E. (1992). The Lord's Prayer in the Gospel of Matthew. Review \& Expositor, 89(2), 215-228. https://doi. org $/ 10.1177 / 003463739208900205$

Gibson, J. B. (2001). Matthew 6:9-13//Luke 11:2-4: An Eschatological Prayer? Biblical Theology Bulletin, 31(3), 96-105. https://doi.org/10.1177/014610790103100304

Gielen, M. (2009). »Und führe uns nicht in Versuchung«. Die 6. Vater-Unser Bitte - eine Anfechtung für das biblische Gottesbild? Zeitschrift Für Die Neutestamentliche Wissenschaft Und Die Kunde Der Älteren Kirche, 89(3-4), 201-216. https://doi.org/10.1515/zntw.1998.89.3-4.201

Goodacre, M. S. (2001). The synoptic problem: A way through the maze. Sheffield Academic Press.

Goodacre, M. S. (2002). The Case Against Q: Studies in Markan Priority and the Synoptic Tradition. Trinity Press International.

Goulder, M. D. (1963). The Composition of the Lord's Prayer. The Journal of Theological Studies, 14(1), 32-45. https://doi.org/10.1093/jts/XIV.1.32

Goulder, Michael Douglas. (1989). Luke: A new paradigm (Vols. 1-2). Sheffield Academic Press.

Grant, R. M. (1949). “One Hundred Fifty-Three Large Fish” (John 21:11). Harvard Theological Review, 42(4), 273-275. https://doi.org/10.1017/S0017816000024329

Grayston, K. (1993). The Decline of Temptation - and the Lord's Prayer. Scottish Journal of Theology, 46(3), 279-296. https://doi.org/10.1017/S0036930600044835

Grigsby, B. (1984). Gematria and John 21 - Another Look at Ezekiel 4710. The Expository Times, 95(6), 177-178. https://doi.org/10.1177/001452468409500607

Grigsby, B. H. (1986). 'If Any Man Thirsts...': Observations on the Rabbinic Background of John 7,37-39. Biblica, 67(1), 101-108. https://doi.org/10.2143/BIB.67.1.3217958

Grintz, J. M. (1960). Hebrew as the Spoken and Written Language in the Last Days of the Second Temple. Journal of Biblical Literature, 79(1), 32-47. https://doi.org/10.2307/3264497

Gryglewicz, F. (1950). Społeczny charakter Modlitwy Pańskiej. Ruch Biblijny i Liturgiczny, 3(3), 207-219. https:// doi.org/10.21906/rbl.2415

Hakola, R. (2017). The Production and Trade of Fish as Source of Economic Growth in the First Century ce Galilee: Galilean Economy Reexamined. Novum Testamentum, 59(2), 111-130. https://doi. org/10.1163/15685365-12341561

Hammerling, R. (2010). The Wondrous Origins of the Lord's Prayer. In R. Hammerling (Ed.), The Lord's Prayer in the Early Church: The Pearl of Great Price (pp.11-44). Palgrave Macmillan. https://doi.org/10.1057/9780230113084_3

Hanhart, K. (1970). The Structure of John I 35 - IV 54. In W. C. van Unnik (Ed.), Studies in John. Presented to Professor Dr. J. N. Sevenster on the Occasion of his Seventieth Birthday (pp. 22-46). Brill. https://doi. org/10.1163/9789004266018_004

Hart, S. (1916). Triangular Numbers. The Journal of Theological Studies, 17(10), 76-77. https://doi.org/10.1093/ jts/os-XVII.10.76

Harvey, A. (2016). Difficult Texts: Matthew 6.11: Daily bread. Theology, 119(6), 403-406. https://doi. org/10.1177/0040571X16659237

Harvey, A. (2018). Daily Bread. The Journal of Theological Studies, 69(1), 25-38. https://doi.org/10.1093/jts/flx242

Heininger, B. (2010). Die Inkulturation des Christentums. Mohr Siebeck. https://doi.org/10.1628/978-3-16-151544-6 
Hemer, C. (1984). 'Eлıoúбเos. Journal for the Study of the New Testament, 7(22), 81-94. https://doi. org/10.1177/0142064X8400702205

Hengel, M. (2008). Die vier Evangelien und das eine Evangelium von Jesus Christus: Studien zu ihrer Sammlung und Entstehung. Mohr Siebeck.

Hennig, J. (1943). Our Daily Bread. Theological Studies, 4(3), 445-454. https://doi.org/10.1177/004056394300400306

Hill, C. E. (1998). The Identity of John's Nathanael. Journal for the Study of the New Testament, 20(67), 45-61. https:// doi.org/10.1177/0142064X9802006703

Holzmeister, U. (1940). Nathanael fuitne idem ac S. Bartholomaeus Apostolus? Biblica, 21(1), 28-39.

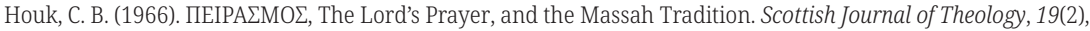
216-225. https://doi.org/10.1017/S0036930600002982

Huggins, R. V. (1992). Matthean Posteriority: A Preliminary Proposal. Novum Testamentum, 34(1), 1-22. https:// doi.org/10.1163/156853692X00131

Hunt, S. A. (2011). Rewriting the Feeding of Five Thousand. John 6.1-15 as a Test Case for Johannine Dependence on the Synoptic Gospels. Peter Lang. https://doi.org/10.3726/978-1-4539-0153-3

Iersel, B. V. (1964). Die wunderbare Speisung und das Abendmahl in der synoptischen Tradition (Mk VI 35-44 par., VIII 1-20 par.). Novum Testamentum, 7(3), 167. https://doi.org/10.2307/1560311

Instone-Brewer, D. (2003). The Eighteen Benedictions and the Minim before $70 \mathrm{CE}$. The Journal of Theological Studies, 54(1), 25-44. https://doi.org/10.1093/jts/54.1.25

International Q Project. creator, Carruth, S., Garsky, A., \& Anderson, S. D. (1996). The database of the international Q project. Q 11:2b-4. Peeters.

Jaworska, M. (2003). Pater noster: Siedem próśb do Ojca. Ateneum Kapłańskie, 140(1), 21-36.

Jeremias, J. (1960). The Lord's Prayer in Modern Research. The Expository Times, 71(5), 141-146. https://doi. org/10.1177/001452466007100504

Kiley, M. (2008). Three More Fish Stories (John 21:11). Journal of Biblical Literature, 127(3), 529-531. https://doi. org/10.2307/25610138

Kimelman, R. (1988). The Daily 'Amidah and the Rhetoric of Redemption. The Jewish Quarterly Review, 79(2-3), 165-197. https://doi.org/10.2307/1454251

Klein, G. (1906). Die ursprüngliche Gestalt des Vaterunsers. Zeitschrift Für Die Neutestamentliche Wissenschaft Und Die Kunde Der Älteren Kirche, 7(1). https://doi.org/10.1515/zntw.1906.7.1.34

Klein, H. (2012). Das Vaterunser: Seine Geschichte und sein Verständnis bei Jesus und im frühen Christentum. In C. Karakolis, H. Klein, V. Mihoc, \& K.-W. Niebuhr (Eds.), Das Gebet im Neuen Testament. Vierte europäische orthodox-westliche Exegetenkonferenz in Sambata de Sus, 4.-8. August 2007 (pp. 77-114). Mohr Siebeck.

Klinghardt, M. (2006). Markion vs. Lukas: Plädoyer für die Wiederaufnahme eines alten Falles. New Testament Studies, 52(4), 484-513. https://doi.org/10.1017/S0028688506000270

Klinghardt, M. (2008). The Marcionite Gospel and the Synoptic Problem: A New Suggestion. Novum Testamentum, 50(1), 1-27. https://doi.org/10.1163/156853608X257527

Knackstedt, J. (1964). Die beiden Brotvermehrungen im Evangelium. New Testament Studies, 10(3), 309-335. https://doi.org/10.1017/S0028688500024231

Knights, C. (2014). Nathanael and Thomas: Two Objectors, Two Confessors - Reading John 20:24-29 and John 1:44-51 in Parallel. The Expository Times, 125(7), 328-332. https://doi.org/10.1177/0014524613494051

Kowalczyk, A. (2002). Łukasz przeredagował Mateuszowi Kazanie na Górze. Studia Gdańskie, 15-16, 27-39.

Kruse, H. (1960). Magni Pisces Centum Quinquaginta Tres. Verbum Domini, 38, 129-149.

Lagrange, M.-J. (1948). Évangile selon Saint Jean (7th ed.). Lecoffre.

Langkammer, T. (1962). Jn 2, 4 w świetle najnowszej egzegezy. Ruch Biblijny i Liturgiczny, 15(2), 82-91. https:// doi.org/10.21906/rbl.2864

Leaney, R. (1957). The Lucan Text of the Lord's Prayer (Lk XI 2-4). Novum Testamentum, 1(1), 103-111. https:// doi.org/10.1163/156853685X00571 
Liebreich, L. J. (1952). The Intermediate Benedictions of the Amidah. The Jewish Quarterly Review, 42(4), 423-426. https://doi.org/10.2307/1453019

Lieu, J. M. (2015). Marcion and the Making of a Heretic: God and Scripture in the Second Century. Cambridge University Press. https://doi.org/10.1017/CBO9781139245876

Lipinski, E. (2011). Q or not Q? The So-Called Triple, Double, and Single Traditions in the Synoptic Gospels. The Polish Journal of Biblical Research, 10(1-2), 164-165.

Lohmeyer, E. (1962). Das Vater-unser (5th ed.). Vandenhoeck \& Ruprecht.

Malina, A. (2013). Bartosz Adamczewski, Q or not Q? The So-Called Triple, Double, and Single Traditions in the Synoptic Gospels, Peter lang, Frankfurt am Main-Berlin-Bruxelles-New York-Oxford-Wien 2010, $554 \mathrm{~s}$. Śląskie Studia Historyczno-Teologiczne, 46(2), 468-479.

Marmorstein, A. (1925). The Amidah of the Public Fast Days. The Jewish Quarterly Review, 15(3), 409-418. https:// doi.org/10.2307/1451587

Martin, M. (2006). A Note on the Two Endings of John. Biblica, 87(4), 523-525. https://doi.org/10.2143/ BIB.87.4.3189067

Martin, M. W. (2015). The Poetry of the Lord's Prayer: A Study in Poetic Device. Journal of Biblical Literature, 134(2), 347-372. https://doi.org/10.15699/jbl.1342.2015.2804

Marucci, C. (2004). Il significato del numero 153 in Gv 21,11. Rivista Biblica, 52(4), 403-440.

Mateja, L. (2017). Dwie wersje Modlitwy Pańskiej odczytane w kluczu inicjacyjnym. Vox Patrum, 67, 389-401. https://doi.org/10.31743/vp.3406

McEleney, N. J. (1977). 153 Great Fishes (John 21,11) - Gematriacal Atbash. Biblica, 58(3), 411-417.

Mędala, S. (1993). Problem struktury literackiej czwartej Ewangelii. Ruch Biblijny i Liturgiczny, 46(1), 11-17. https://doi.org/10.21906/rbl.1020

Mendecki, N. (1984). Modlitwa „osiemnastu błogosławieństw”. Ruch Biblijny i Liturgiczny, 37(2), 140-143. https:// doi.org/10.21906/rbl.1270

Menken, M. J. J. (2014). Numerical Literary Techniques in John. The Fourth Evangelist's Use of Numbers of Words and Syllables. Brill. https://brill.com/view/title/6492

Mickiewicz, F. (2011). Ewangelia według św. Łukasza. Cz. 1: Rozdziały 1-11. Edycja Świętego Pawła.

Minear, P. S. (1983). The Original Functions of John 21. Journal of Biblical Literature, 102(1), 85-98. https://doi. org/10.2307/3260747

Mishcon, A. (1927). The Origin of את צמח דוד and Its Place in the 'Amidah, The Jewish Quarterly Review, 18(1), 37-43. https://doi.org/10.2307/1451757

Moll, S. (2010). The Arch-Heretic Marcion. Mohr Siebeck. https://doi.org/10.1628/978-3-16-151539-2

Montefiore, H. (1962). Revolt in the Desert? New Testament Studies, 8(2), 135-141. https://doi.org/10.1017/ S0028688500005890

Mróz, M. (Ed.). (2005). Stowa nadziei. Prośby Modlitwy Pańskiej. Wydawnictwo Uniwersytetu Mikołaja Kopernika.

Mucha, P. M. (2009). Mother of the Lord and the 153 large fishes in John 21: 11. Ruch Biblijny i Liturgiczny, 62(4), 297-302. https://doi.org/10.21906/rbl.222

Mucha, P. M. (2013). What was the Origin of Number 153? Ruch Biblijny i Liturgiczny, 66(2), 101-125. https://doi. org/10.21906/rbl.62

Mucha, P. M. (2018). Matka Pana a apokaliptyczne trzęsienia ziemi. Ruch Biblijny i Liturgiczny, 71(4), 363-367. https://doi.org/10.21906/rbl.3623

Muchowski, P. (1998). Język hebrajski qumrański, jego zasięg i status społeczny. Ruch Biblijny i Liturgiczny, 51(3), 161-168. https://doi.org/10.21906/rbl.670

Nalewaj, A. (2010). „Matka Jezusa” i „Niewiasta” jako tytuły Maryi w czwartej Ewangelii. Ruch Biblijny i Liturgiczny, 63(1), 13-30. https://doi.org/10.21906/rbl.158

Nalewaj, A. (2012). Analiza porównawcza struktury literackiej i motywów teologicznych w J 2, 1-12 i 20, 1-18. Studia Warmińskie, 49, 107-121. https://doi.org/10.31648/sw.257 
Neirynck, F. (1990). Response to the Multiple Stage Hypothesis, I: The Introduction to the Feeding Story. In D. L. Dungan (Ed.), The Interrelation of the Gospels: A Symposium Led by M.E. Boismard, WR. Framer, F. Neirynck, Jerusalem 1984 (pp. 81-93). Louvain University Press.

Neirynck, Frans. (1990). John 21. New Testament Studies, 36(3), 321-336. https://doi.org/10.1017/S0028688500015770 Neumann, J. N. (2019). Thy Will Be Done: Jesus's Passion in the Lord’s Prayer. Journal of Biblical Literature, 138(1), 161-182. https://doi.org/10.15699/jbl.1381.2019.524397

Oakman, D. E. (2017). The Political Meaning of a Cipher - John 21:11: In memory of an unforgettable friend and scholar John J. Pilch. Biblical Theology Bulletin, 47(2), 87-94. https://doi.org/10.1177/0146107917697904

Oberweis, M. (2009). Die Bedeutung der neutestamentlichen »Rätselzahlen« 666 (Apk 13 18) und 153 (Joh 21 11). Zeitschrift Für Die Neutestamentliche Wissenschaft Und Die Kunde Der Älteren Kirche, 77(3-4), 226-241. https:// doi.org/10.1515/zntw.1986.77.3-4.226

O'Collins, G. (2019). 'His Life Rose With Him' - John 21 and the Resurrection of Jesus. Irish Theological Quarterly, 84(2), 195-211. https://doi.org/10.1177/0021140019829327

O'Donovan, O. (2009). Prayer and Morality in the Sermon on the Mount. Studies in Christian Ethics, 22(1), 21-33. https://doi.org/10.1177/0953946808100224

O'Neill, J. C. (1993). The Lord's Prayer. Journal for the Study of the New Testament, 16(51), 3-25. https://doi. org/10.1177/0142064X9301605101

Ostański, P. (2002a). Bibliografia biblistyki polskiej 1945-1999 (Vol. 1). Uniwersytet im. Adama Mickiewicza Wydział Teologiczny Redakcja Wydawnictw.

Ostański, P. (2002b). Bibliografia biblistyki polskiej 1945-1999 (Vol. 2). Uniwersytet im. Adama Mickiewicza Wydział Teologiczny Redakcja Wydawnictw.

Ostański, P. (2010a). Bibliografia biblistyki polskiej 2000-2009 (Vol. 3). Uniwersytet im. Adama Mickiewicza Wydział Teologiczny Redakcja Wydawnictw.

Ostański, P. (2010b). Bibliografia biblistyki polskiej 2000-2009 (Vol. 4). Uniwersytet im. Adama Mickiewicza Wydział Teologiczny Redakcja Wydawnictw.

Ostański, P. (2015). Bibliografia biblistyki polskiej 2010-2013/2014 (Vol. 5). Uniwersytet im. Adama Mickiewicza Wydział Teologiczny.

Ostmeyer, K.-H. (2005). Armenhaus und Räuberhöhle? Galiläa zur Zeit Jesu. Zeitschrift Für Die Neutestamentliche Wissenschaft Und Die Kunde Der Älteren Kirche, 96(3-4), 147-170. https://doi.org/10.1515/zntw.2005.96.3-4.147

Owen, O. T. (1988). One Hundred and Fifty Three Fishes. The Expository Times, 100(2), 52-54. https://doi. org/10.1177/001452468810000204

Paciorek, A. (2001). Q - Ewangelia Galilejska. Towarzystwo Naukowe Katolickiego Uniwersytetu Lubelskiego.

Paciorek, A. (2003). Nowa modlitwa uczniów Nowego Przymierza (Mt 6, 9-13). Verbum Vitae, 4, 157-175.

Pesch, R. (1969). Der reiche Fischfang, Lk 5,1-11/Jo 21,1-14 Wundergeschichte, Bernfungserzählung, Erscheinungsbericht. Patmos-Verlag.

Phillips, T. E. (2011). Q or Not Q? The So-Called Triple, Double, and Single Traditions in the Synoptic Gospels - By Bartosz Adamczewski. Religious Studies Review, 37(2), 130-130. https://doi.org/10.1111/j.1748-0922.2011.01513_7.x

Pitta, A. (1990). Ichthys ed opsarion in Gv 21,1-14: Semplice variazione lessicale o differenza con valore simbolico? Biblica, 71(3), 348-364. https://doi.org/10.2143/BIB.71.3.3217765

Ponomariov, A. (2015). The Lord's prayer in a wider setting: A new Hebrew reconstruction. Journal of Northwest Semitic Languages, 41(1), 71-100.

Poon, W. C. K. (2003). Superabundant Table Fellowship in the Kingdom: The Feeding of the Five Thousand and the Meal Motif in Luke. The Expository Times, 114(7), 224-230. https://doi.org/10.1177/001452460311400703

Popkes, W. (1990). Die letzte Bitte des Vater-Unser Formgeschichtliche Beobachtungen zum Gebet Jesu. Zeitschrift Für Die Neutestamentliche Wissenschaft Und Die Kunde Der Älteren Kirche, 81(1-2), 1-20. https://doi. org/10.1515/zntw.1990.81.1-2.1 
Rapinchuk, M. (2004). The Galilee and Jesus in Recent Research. Currents in Biblical Research, 2(2), 197-222. https://doi.org/10.1177/1476993X0300200204

Rastoin, M. (2009). Encore une fois les 153 poissons (Jn 21,11). Biblica, 90(1), 84-92. https://doi.org/10.2143/ BIB.90.1.3188895

Review of Q or Not Q? The So-Called Triple, Double, and Single Traditions in the Synoptic Gospels by Bartosz Adamczewski. (2012). [by R. B. Vinson]. The Catholic Biblical Quarterly, 74(1), 141-142.

Romeo, J. A. (1978). Gematria and John 21:11: The Children of God. Journal of Biblical Literature, 97(2), 263-264. https://doi.org/10.2307/3265625

Roose, H. (2003). Joh 20,30f.: Ein (un)passender Schluss? Joh 9 und 11 als primäre Verweisstellen der Schlussnotiz des Johannesevangeliums. Biblica, 84(3), 326-343. https://doi.org/10.2143/BIB.84.3.3194477

Rosik, M. (2008). Judaistyczne tło Modlitwy Pańskiej (Mt 6, 9-13). Zeszyty Naukowe Centrum Badań Im. Edyty Stein, 4, 41-49.

Rosik, Mariusz. (2011). Judaistyczne tło Modlitwy Pańskiej (Mt 6, 9-13) w świetle idei ojcostwa Bożego w Kazaniu na górze. Verbum Vitae, 20, 115-138.

Ross, J. M. (1989). One Hundred and Fifty-Three Fishes. The Expository Times, 100(10), 375. https://doi. org/10.1177/001452468910001005

Roth, D. (2008). Marcion's Gospel and Luke: The History of Research in Current Debate. Journal of Biblical Literature, 127(3), 513. https://doi.org/10.2307/25610137

Roth, D. T. (2012). The Text of the Lord's Prayer in Marcion's Gospel. Zeitschrift Für Die Neutestamentliche Wissenschaft Und Die Kunde Der Älteren Kirche, 103(1). https://doi.org/10.1515/znw-2012-0003

Roth, W. M. W. (1962). The Numerical Sequence $\mathrm{x} / \mathrm{x}+1$ in the Old Testament. Vetus Testamentum, 12(1), 300-311. https://doi.org/10.1163/156853362X00182

Salm, A. (2010). „Nie dopuść, abyśmy ulegli pokusie” - od Pisma Świętego do codziennej liturgii i modlitwy. Ruch Biblijny i Liturgiczny, 63(1), 73-77. https://doi.org/10.21906/rbl.162

Schürmann, H. (1981). Das Gebet des Herrn als Schlussel zum Verstehen Jesu (4th ed.). Herder.

Schwarz, G. (1969). Matthäus VI. 9-13/Lukas XI. 2-4: Emendation und Rückübersetzung. New Testament Studies, 15(2), 233-247. https://doi.org/10.1017/S0028688500019068

Schweizer, E. (1984). The good news according to Luke. John Knox Press.

Shearman, T. G. (1934). Our Daily Bread. Journal of Biblical Literature, 53(2), 110-117. https://doi.org/10.2307/3259878 Smereka, W. (1956). Ecce Mater Tua. Ruch Biblijny i Liturgiczny, 9(4-6), 244-261. https://doi.org/10.21906/rbl.2590 Spencer, P. E. (2000). Narrative Echoes in John 21: Intertextual Interpretation and Intratextual Connection. Journal for the Study of the New Testament, 22(75), 49-68. https://doi.org/10.1177/0142064X0002207504

Stanton, G. (2002). The Gospels and Jesus (2nd ed.). Oxford University Press.

Stegner, W. R. (1976). Lukan Priority in the Feeding of the Five Thousand. Chicago Society of Biblical Research, 21, 19-28.

Talavero Tovar, S. (2012). Sobre los 153 peces en Jn 21,11. ¿Encierra el 153 un notarikón? ¿Remite a los no judíos? Liber Annuus, 62, 107-117. https://doi.org/10.1484/J.LA.5.101302

Trudinger, P. (1989). The 'Our Father’ in Matthew as Apocalyptic Eschatology: The Downside Review, 107(366), 49-54. https://doi.org/10.1177/001258068910736604

Tyson, J. B. (2006). Marcion and Luke-Acts. A defining struggle. University of South Carolina Press.

Van Tilborg, S. (1972). A Form-Criticism of the Lord's Prayer. Novum Testamentum, 14(2), 94-105. https://doi. org/10.2307/1560176

Von Dobschütz, E. (1914). The Lord's Prayer. Harvard Theological Review, 7(3), 293-321. https://doi.org/10.1017/ S0017816000011433

Waite, C. B. (1881). History of the Christian religion to the year two hundred (2nd ed.). C. V. Waite.

Wenham, D. (2010). The Sevenfold Form of the Lord's Prayer in Matthew's Gospel. The Expository Times, 121(8), 377-382. https://doi.org/10.1177/0014524610364409 
Wilke, C. G. (1838). Der Urevangelist oder exegetisch kritische Untersuchung über das Verwandtschaftsverhältniss der drei ersten Evangelien. Gerhard Fleischer.

William, L. (1922). The Origin of the Gospels. The Church Quarterly Review, 94, 216-239.

Wojciechowski, M. (1984). Certains aspects algébriques de quelques nombres symboliques de la Bible (Gen 5; Gen 14, 14; Jn 21, 11). Biblische Notizen, 23, 29-31.

Wróbel, R. (2007). Chrystofania nad Jeziorem Tyberiadzkim (J 21, 1-14). Problemy interpretacyjne i znaczenie. Ruch Biblijny i Liturgiczny, 60(3), 185-208. https://doi.org/10.21906/rbl.371

Zbroja, B. (2012). Teologia wypowiedzi Jezusa z krzyża. Ruch Biblijny i Liturgiczny, 65(3), 211-224. https://doi. org/10.21906/rbl.94

Ziener, G. (1960). Das Brotwunder im Markusevangelium. Biblische Zeitschrift, 4, 282-285.

Żychlińska, B. (2001). Liczba trzy w Tradycji Łukaszowej. Ruch Biblijny i Liturgiczny, 54(4), 295-302. https://doi. org/10.21906/rbl.3580 